\title{
A Diels-Alder Reaction Between A Cigarette Mainstream Smoke Component and Benzoquinone*
}

\author{
by \\ W. M. Coleman, III \\ R. J. Reynolds Tobacco Company, P.O. Box 1487, Winston-Salem, NC 27102-1487, USA
}

\section{SUMMARY}

A notable amount of research has been placed toward understanding the roles of benzoquinone $(\mathrm{Q})$ and hydroquinone (HQ) in the chemistry and toxicity of cigarette smoke. To further understanding of the roles of these compounds in cigarette smoke, a series of reactions were performed wherein the levels and chemistries of Q and HQ were monitored after having been added to selected phases of the mainstream smoke from 2R4F cigarettes. Through the application of both fundamental organic chemistry reaction mechanistic principles and qualitative analysis of smoke chemistry, a new reaction pathway for mainstream smoke components was elucidated. During the course of these investigations, the presence of a product from a Diels-Alder reaction between a 2R4F cigarette mainstream smoke component and Q was discovered. Data from carbon-13 nuclear magnetic resonance $\left({ }^{13} \mathrm{C} \mathrm{NMR}\right)$, gas chromatography-atomic emission detection (GC-AED), and gas chromatography-mass selective detection (GCMSD) revealed a Diels-Alder reaction product resulting from the reaction of benzoquinone $(\mathrm{Q})$, a dienophile, and 1,3-cyclopentadiene, a diene, to yield tricyclo[6.2.1.0 $\left.0^{2,7}\right]$ undeca-4,9-diene-3,6-dione, more commonly referred to as cyclopentadienebenzoquinone. The reaction between $\mathrm{Q}$ and 1,3-cyclopentadiene was observed to have occurred when fresh mainstream vapor phase smoke (MSVP) from a 2R4F cigarette, captured in acetone, was subsequently treated with $\mathrm{Q}$. Other ${ }^{13} \mathrm{C}$ containing species were detected but inadequate signal to noise values prevented structural assignments. Accompanying the Diels-Alder reaction was an additional reaction of $\mathrm{Q}$ to form hydroquinone (HQ). These reactions provide additional information on the complexity of cigarette smoke, particularly as it relates to possible reactions involving $\mathrm{Q}$ and HQ and other cigarette smoke components. [Beitr. Tabakforsch. Int. 23 (2008) 121-136]

\section{ZUSAMMENFASSUNG}

Es wurden bisher beachtlich viele Untersuchungen durchgeführt, um die Rolle von Benzochinon (Q) und Hydrochinon (HQ) bei der Chemie und Toxizität des Zigarettenrauchs zu verstehen. Um das Verständnis über die Rolle dieser Verbindungen für die Eigenschaften des Zigarettenrauchs zu vertiefen, wurden mehrere Versuche durchgeführt, bei denen das mengenmäßige Vorkommen und die chemischen Eigenschaften von Q und HQ untersucht wurden, nachdem diese bestimmten Phasen des Hauptstromrauchs von 2R4F Zigaretten zugeführt wurden. Durch die Anwendung der Prinzipien, die den Reaktionsmechanismen der organischen Chemie zugrunde liegen und der qualitativen analytischen Rauchchemie, wurde ein neuer Ansatz für die Untersuchung der Hauptstromrauchinhaltsstoffe beleuchtet. Während dieser Untersuchungen wurde die Gegenwart eines Reaktionsproduktes entdeckt, das bei einer Diels-Alder Reaktion zwischen einem Inhaltsstoff des Hauptstromrauchs einer 2R4F Zigarette und Q entstanden ist. Mittels kernmagnetischer Resonanzspektroskopie ( $\left.{ }^{13} \mathrm{C} \mathrm{NMR}\right)$, gaschromatographischer Atomemissionsdetektion (GC-AED) und GaschromatographieMassenspektrometrie (GC-MSD) erhobene Daten zeigten ein Diels-Alder Reaktionsprodukt, das aus der Reaktion von Benzochinon (Q), eines Dienophils und 1,3-Cyclopentadien, eines Diens, entstanden ist, wobei es sich um Tricyclo[6.2.1.0 $\left.0^{2,7}\right]$ undeca-4,9-dien-3,6-dion handelt, das bekannt ist unter dem Namen Cylcopentadienebenzochinon. Es wurde beobachtet, dass die Reaktion zwischen $\mathrm{Q}$ und 1,3-Cyclopentadien stattfand, wenn die Gasphasen frischen Hauptstromrauchs (MSVP) einer 2R4F Zigarette, die mit Aceton eingefangen wurde, nachfolgend mit $\mathrm{Q}$ behandelt wurde. Andere Substanzen, die ${ }^{13} \mathrm{C}$ enthielten, wurden entdeckt, eine strukturelle Zuordnung konnte jedoch aufgrund zu kleiner Signale nicht erfolgen. Zusätzlich zur Diels-Alder Reaktion erfolgte eine Reaktion 
von Q zu Hydrochinon (HQ). Diese Reaktionen liefern zusätzliche Informationen über die Komplexität des Zigarettenrauchs, insbesondere wenn es zu möglichen Reaktionen der Substanzen Q und HQ und anderen Inhaltsstoffen des Zigarettenrauchs kommt. [Beitr. Tabakforsch. Int. 23 (2008) 121-136]

\section{RESUME}

De nombreuses recherches ont été conduites pour examiner le rôle que jouent les benzoquinones (Q) et les hydroquinones (HQ) pour les propriétés chimiques et toxiques de la fumée de cigarettes. Pour mieux comprendre le rôle que jouent ces composants dans la fumée de cigarette, plusieurs études ont été conduites pour examiner les concentrations et les propriétés chimiques des substances Q et HQ après avoir été ajoutées aux phases de la fumée du courant principal de cigarettes 2R4F. Par l'application des principes du mécanisme des réactions de la chimie organique et des analyses de la chimie de la fumée, une nouvelle voie de réaction des composants de la fumée principale a été élucidée. Au cours de ces études, la présence d'une nouvelle substance produite par une réaction Diels-Alder entre un composant de la fumée principale d'une cigarette $2 \mathrm{R} 4 \mathrm{~F}$ et la substance $\mathrm{Q}$ a été trouvée. Les données obtenus par résonance magnétique nucléaire au ${ }^{13} \mathrm{C}\left({ }^{13} \mathrm{C}-\mathrm{RMN}\right)$, chromatographie en phase gazeuse détection par émission atomique(GC-AED), et chromatographie en phase gazeuse-détection sélective des masses (GC-MSD) ont révélé la présence d'un produit de réaction Diels-Alder, résulté de la réaction du benzoquinone $(\mathrm{Q})$, un diènophile, et du 1,3-cyclopentadiène, un diène, pour former le tricyclo[6,2,1,0]undeca-4,9-diène3,6-dione, plus couramment nommé cyclopentadiènebenzoquinone. Il a été observé que la réaction entre $\mathrm{Q}$ et 1,3-cyclopentadiene se produira quand la fumée fraîche du courant principal en phase gazeuse (MSVP) d'une cigarette 2R4F, échantillonnée dans de l'acétone, a consécutivement été traitée avec Q. D'autres produits contenant $\mathrm{du}{ }^{13} \mathrm{C}$ ont été trouvés mais l'attribution structurale a été empêchée par des valeurs signal/bruit inadéquates. Dans une réaction supplémentaire de la substance Q, l'hydroquinone (HQ) a été produite. Ces réactions donnent une information supplémentaire sur la complexité de la fumée de cigarette, particulièrement en ce qui concerne les réactions possibles des substances Q et HQ avec les autres composants de la fumée de cigarette. [Beitr. Tabakforsch. Int. 23 (2008) 121-136]

\section{INTRODUCTION}

For a number of years, cigarette smoke has been realized to be a complex mixture of organic and inorganic species (1). The chemical complexity of cigarette smoke is strongly dependent on the heating conditions inside the lit cigarette (2). Recently, special emphasis has been placed on investigations related to the redox chemistry and free radical content of cigarette smoke $(3,4)$. In addition, a notable amount of effort has been placed towards understanding the role and levels of selected hydroxybenzenes, benzoquinone, $\mathrm{Q}$, and hydroquinone, HQ, in the chemistry and toxicity of cigarette smoke, as well as in their chemistries and toxicities (5-19). A significant portion of the understanding and focus has centered about the free radical nature of the hydroquinonesemiquinone-quinone reaction and the potential of this reaction to influence the nature of cigarette smoke (5-15). The postulated presence of a semi-quinone radical in cigarette smoke directly infers by default the real possibility of Q being present in cigarette smoke. However, benzoquinone has been well known for some time as a dienophile in the now famous Diels-Alder reaction involving dienophiles and dienes (16-19). In fact, the reactions between benzoquinone and dienes culminated in the Nobel Prize in Chemistry for Professor OTTO DIELS and his student KURT ALDER in $1950(18,19)$. The initial investigations concerning these reactions took place in 1928. Dienes such as 1,3-butadiene and cyclopentadiene, are also known constituents of cigarette smoke, with, for example, 1,3-butadiene yields in the range of $40 \mu \mathrm{g} /$ cigarette $(20,21)$. Cyclopentadiene has been shown to be a pyrolysis product of cellulose, a major tobacco ingredient (22), and a component of tobacco smoke $(1,23)$. It is of note that Diels-Alder reaction products involving 1,3-butadiene and cyclopentadiene have been patented as flavor tobacco additives (24).

Gas chromatography-atomic emission detection (GCAED) provides for an ideal means of determining the fate of a molecule(s) present in a reactive/complex mixture, particularly if the molecule(s) of interest is composed of certain elements, such as phosphorus, sulfur, or nitrogen (25-34). The AED approach is based on the generation of atomic species from degradation of organic molecules in a microwave plasma (25-31). In a recent study, the fate of deuterium (D) labeled compounds was determined in mainstream and sidestream tobacco smoke. More specifically, the fates of nicotine- $\mathrm{d}_{4}$ and pyridine- $\mathrm{d}_{5}$ were monitored after their addition to the tobacco rod of full flavor cigarettes $(32,33)$. GC-AED approaches have also been defined for monitoring the fate of ${ }^{13} \mathrm{C}$ labeled compounds in the presence of ${ }^{12} \mathrm{C}$ species (34). For the purpose of this study, these GC-AED techniques have been applied in an attempt to provide some information on the nature of the structures of the compounds that result from reactions of HQ and Q within smoke matrices. When coupled with a gas chromatographic separation, the AED will be shown to provide informative new data on ${ }^{13} \mathrm{C}$ isotope enriched products closely linked on a structural basis to the depletion of ${ }^{13} \mathrm{C}_{6} \mathrm{Q}$ when added into an acetone solution of 2R4F vapor-phase (VP) smoke. Matching the GC-AED chromatographic separation using a gas chromatography-mass selective detection (GC-MSD) will be revealed to provide for confident structural assignments of the ${ }^{13} \mathrm{C}_{6} \mathrm{Q}$ reaction products.

Carbon-13 nuclear magnetic resonance $\left({ }^{13} \mathrm{C}\right.$ NMR $)$ techniques are very powerful analytical probes for determining the structure of organic and organo-metallic compounds $(35,36)$. The chemical nature of the carbon centers is such as to allow for accurate conclusions as to the structure and spatial arrangements of the atoms. However, quantitative assessments as to the ratio of particular types of carbons are not as trivial as for protons due mainly to substantial differences in spin-lattice relaxation times, $T_{1}$. 
Table 1. Gas chromatography-atomic emission detection (GC-AED) operating conditions

\begin{tabular}{ll}
\hline System configuration & Agilent $6890 \mathrm{GC}$ equipped with a G2350 AED (Wilmington, DL, USA) \\
Column & DB- 170130 meters, $0.25 \mathrm{~mm}$ i.d., $0.25 \mu \mathrm{m}$ film thickness \\
Injection port temperature & $280{ }^{\circ} \mathrm{C}$ \\
Injection & Splitless \\
Column flow & Constant, $1 \mathrm{~mL} / \mathrm{min} \mathrm{He}$ \\
Column oven initial temperature & $50{ }^{\circ} \mathrm{C}$ \\
Column oven initial time & $0 \mathrm{~min}$ \\
Column oven initial ramp 1 rate & $2.5^{\circ} \mathrm{C} / \mathrm{min}$ \\
Column oven 1 final temperature & $90{ }^{\circ} \mathrm{C}$ \\
Column oven 1 final time & $0 \mathrm{~min}$ \\
Column oven ramp 2 rate & $10^{\circ} \mathrm{C} / \mathrm{min}$ \\
Column oven 2 final temperature & $280^{\circ} \mathrm{C}$ \\
Column oven 2 final time & $0 \mathrm{~min}$ \\
Elements & $\mathrm{Carbon}-12177 \mathrm{~nm}$, Carbon- $13,177 \mathrm{~nm}$ \\
AED vent times & $\mathrm{On}$ at $2.5 \mathrm{~min}$, Off at $5.00 \mathrm{~min}$ \\
Hydrogen pressure & $8.3 \mathrm{psi}$ \\
Oxygen pressure & $35.5 \mathrm{psi}$ \\
Purge vent flow & $32 \mathrm{~mL} / \mathrm{min}$ \\
Cavity vent flow & $61 \mathrm{~mL} / \mathrm{min}$ \\
Cavity pressure & $1.5 \mathrm{psi}$ \\
AED transfer line temperature & $280^{\circ} \mathrm{C}$ \\
AED cavity temperature & $290{ }^{\circ} \mathrm{C}$ \\
\hline
\end{tabular}

Use of uniformly labeled (enriched) ${ }^{13} \mathrm{C}$ substrates dramatically facilitates the ${ }^{13} \mathrm{C}$ NMR experiment due primarily to the relatively low natural abundance of ${ }^{13} \mathrm{C},<1 \%$. The presence of the labeled material not only improves the signal to noise ratio but also can provide for the observation of the labeled carbon atoms prior to significant responses from non-labeled carbons from species that may be present in the sample. In addition, the presence of carbon-carbon $\left({ }^{13} \mathrm{C}-{ }^{13} \mathrm{C}\right)$ coupling constants, provides for split ${ }^{13} \mathrm{C}$ resonances that are not present in natural abundance ${ }^{13} \mathrm{C}$ spectra. Recently, tobacco smoke particulate matter chemistry has been examined using ${ }^{13} \mathrm{C}$ NMR (37). For the purpose of this study, similar ${ }^{13} \mathrm{C}$ NMR techniques have been applied that will be shown to provide meaningful information on the nature of the structures of the components that result from reactions of $\mathrm{HQ}$ and $\mathrm{Q}$ within smoke matrices.

Thus, based in part on the information surrounding the characteristics of mainstream cigarette smoke as portrayed by hydroxybenzenes, the chemical complexity of mainstream cigarette smoke, as well as smoke chemistries disclosed within additional reports $(38,39)$, the dynamic reactivity of mainstream cigarette smoke would seem to have been confirmed and well documented. In this report is described yet another reaction between reasonably well known cigarette smoke components. Data collected via GC-AED, GC-MSD and ${ }^{13} \mathrm{C}$ NMR provide information on an additional reaction pathway(s), like Diels-Alder reactions, in the complex chemistry of the hydroquinone-semiquinone-quinone shuttle as it possibly relates to mainstream cigarette smoke.

\section{EXPERIMENTAL SECTION}

\section{Chemicals}

Acetone- $\mathrm{d}_{6}$, acetone, and cyclopentadienebenzoquinone were obtained from Sigma-Aldrich Corporation, St. Louis,
MO, USA. Hydroquinone ${ }^{13} \mathrm{C}_{6}$ and quinone ${ }^{13} \mathrm{C}_{6}$ were obtained from IsoSciences, King of Prussia, PA, USA. Solutions of known concentration of hydroquinone ${ }^{13} \mathrm{C}_{6}$ and quinone ${ }^{13} \mathrm{C}_{6}$ were prepared in either acetone $\mathrm{d}_{6}$ or acetone as required.

\section{Instrumentation}

Decoupled ${ }^{13} \mathrm{C}$ NMR spectra were obtained on a Varian (Palo Alto, CA, USA) High Resolution 400 MHz NMR Spectrometer.

GC-AED analysis conditions appear in Table 1. GC-MSD analysis conditions appear in Table 2 .

\section{Smoke sample preparation for NMR analyses (see Scheme 1)}

Mainstream smoke samples from $2 \mathrm{R} 4 \mathrm{~F}$ reference cigarettes (University of Kentucky, Lexington, KY, USA) were collected on a Heinrich Borgwaldt RM20 rotary smoke engine (Heinreich Borgwaldt $\mathrm{GmbH}$, Hamburg, Germany). The smoking regimen used to collect samples was $35 / 60 / 2$; a $35 \mathrm{~mL}$ puff taken every 60 seconds with a 2 second puff duration. Cigarettes and Cambridge ${ }^{\mathrm{TM}} 44 \mathrm{~mm}$ pads (Performance Systematix, Inc., Grand Rapids, MI, USA) were conditioned prior to smoking, for a minimum of 48 hours, in a laboratory with an environment of $75 \pm$ $2^{\circ} \mathrm{F}$ and relative humidity at $60 \pm 2 \%$. The air velocity of the machine was set using a Lambrecht Thermoanemometer and the puff volume of the smoking machine was verified with a Soap Bubble Flow Meter to be $35 \pm 0.5 \mathrm{~mL}$. The machine was checked for leaks using a leakage tester at each of the 20 ports prior to smoking. For VP collection, twin $100 \mathrm{~mL}$ impingers, connected in series, were placed between the Cambridge ${ }^{\mathrm{TM}}$ pad and the syringe of the smoke machine. The impingers were each filled with $25 \mathrm{~mL}$ of acetone- $\mathrm{d}_{6}$ and chilled to $-70{ }^{\circ} \mathrm{C}$, in 


\begin{tabular}{|c|c|}
\hline System configuration & Agilent 6890 GC equipped with a 5973 MSD (Wilmington, DL, USA) \\
\hline Column & DB-1701 30 meters, $0.25 \mathrm{~mm}$ i.d., $0.25 \mu \mathrm{m}$ film thickness \\
\hline Injection port temperature & $280{ }^{\circ} \mathrm{C}$ \\
\hline Injection & Splitless \\
\hline Column flow & Constant, $0.6 \mathrm{~mL} / \mathrm{min} \mathrm{He}$ \\
\hline Column oven initial temperature & $50^{\circ} \mathrm{C}$ \\
\hline Column oven initial time & $0 \mathrm{~min}$ \\
\hline Column oven initial ramp 1 rate & $2^{\circ} \mathrm{C} / \mathrm{min}$ \\
\hline Column oven 1 final temperature & $80^{\circ} \mathrm{C}$ \\
\hline Column oven 1 final time & $0 \mathrm{~min}$ \\
\hline Column oven ramp 2 rate & $9.8^{\circ} \mathrm{C} / \mathrm{min}$ \\
\hline Column oven 2 final temperature & $280{ }^{\circ} \mathrm{C}$ \\
\hline Column oven 2 final time & $0 \mathrm{~min}$ \\
\hline Mass spectrometer transfer line temp & $280^{\circ} \mathrm{C}$ \\
\hline Mass spectral databases & NBS, Wiley \\
\hline Mass spectrometer configuration & Electron impact, $70 \mathrm{eV}$ \\
\hline
\end{tabular}

Scheme 1. Synopsis of sample preparation, sample identification, measurements and figure locations ${ }^{\text {a }}$

\begin{tabular}{|c|c|c|c|}
\hline Sample preparation & Sample identification & Measurements & Data in Figure \\
\hline $\begin{array}{l}\text { MSVP smoke from } 152 \mathrm{R} 4 \mathrm{~F} \text { cigarettes in } \\
\text { acetone trap }+0.8 \mu \mathrm{g}^{13} \mathrm{C}_{6} \mathrm{Q}\end{array}$ & Q1 & $\begin{array}{l}\text { 1) NMR, }<24 \text { hrs } \\
\text { 2) Initial GC-AED }\end{array}$ & 9 \\
\hline $\begin{array}{l}\text { MSVP smoke from } 152 \mathrm{R} 4 \mathrm{~F} \text { cigarettes in } \\
\text { acetone trap+ } 0.8 \mu \mathrm{g}^{13} \mathrm{C}_{6} \mathrm{HQ}\end{array}$ & HQ1 & $\begin{array}{l}\text { 1) NMR, }<24 \mathrm{hrs} \\
\text { 2) Initial GC-AED }\end{array}$ & 8 \\
\hline $\begin{array}{c}\text { MSPP smoke from } 202 \mathrm{R} 4 \mathrm{~F} \text { cigarettes }+ \\
800 \mu \mathrm{g}{ }^{13} \mathrm{C}_{6} \mathrm{Q} \text { on pad, acetone extract }\end{array}$ & Q2 & 1) NMR, <24 hrs & \\
\hline $\begin{array}{l}\text { MSPP smoke from } 202 R 4 F \text { cigarettes }+ \\
800 \mu{ }^{13} \mathrm{C}_{6} \mathrm{HQ} \text { on pad, acetone extract }\end{array}$ & HQ2 & $\begin{array}{l}\text { 1) } \mathrm{NMR},<24 \mathrm{hrs} \\
\text { 2) Initial GC-AED }\end{array}$ & 7 \\
\hline $\begin{array}{l}\text { MSVP smoke from } 12 R 4 F \text { cigarette in } \\
\text { acetone trap }+263 \mu \mathrm{g}^{12} \mathrm{C}_{6} \mathrm{Q}\end{array}$ & Q3 & $\begin{array}{l}\text { 1) GC-AED } \\
\text { 2) GC-MSD-ion abundance }\end{array}$ & $13,14,15$ \\
\hline $\begin{array}{l}\text { MSVP smoke from } 12 \mathrm{R} 4 \mathrm{~F} \text { cigarette in } \\
\text { acetone trap }+272 \mu \mathrm{g}{ }^{13} \mathrm{C}_{6} \mathrm{Q}\end{array}$ & Q4 & $\begin{array}{l}\text { 1) GC-MSD, } 48 \mathrm{hrs} \\
\text { 2) GC-MSD, after } 120 \mathrm{hrs} \\
\text { 3) GC-AED, after } 120 \mathrm{hrs} \\
\text { 4) GC-MSD-ion abundance }\end{array}$ & $\begin{array}{l}10,11 \\
12 \\
12 \\
13.14\end{array}$ \\
\hline $\begin{array}{l}\text { MSVP smoke from } 152 \mathrm{R} 4 \mathrm{~F} \text { cigarettes in } \\
\text { acetone trap }+263 \mu \mathrm{g}{ }^{12} \mathrm{C}_{6} \mathrm{Q}\end{array}$ & Q5 & $\begin{array}{l}\text { 1) GC/AED, } 96 \text { hrs at room temperature } \\
\text { 2) GC-MSD, } 96 \text { hrs at room temperature }\end{array}$ & $18,19,20$ \\
\hline $\begin{array}{l}\text { MSVP smoke from } 152 \mathrm{R} 4 \mathrm{~F} \text { cigarettes in } \\
\text { acetone trap }+272 \mu \mathrm{g}{ }^{13} \mathrm{C}_{6} \mathrm{Q}\end{array}$ & Q6 & $\begin{array}{l}\text { 3) GC-AED, } 96 \mathrm{hrs} \text { at room temperature } \\
\text { 4) GC-MSD, } 96 \text { hrs at room temperature }\end{array}$ & $\begin{array}{l}18 \\
19,20\end{array}$ \\
\hline
\end{tabular}

\footnotetext{
${ }^{a}$ Abbreviations: GC- AED = gas-chromatography-atomic emission detection, GC-MSD = gas chromatography-mass selective detection, MSVP = mainstream vapor phase smoke; MSPP = mainstream particulate phase smoke; NMR = nuclear magnetic resonance,
}

an isopropanol/dry ice bath, one hour prior to smoking. Prior to smoking, the puff volume was verified and the machine checked for leaks. Thirty cigarettes were used in the collection, with the pad weight taken prior to and after smoking. The validity of the smoke run was determined by comparison of the wet total particulate matter (WTPM) and puffs/cigarette from the run with those from Federal Trade Commission (FTC) (40) analysis. After collection, the vapor-phase solution was allowed to reach room temperature and the two impinger solutions pooled for sample homogeneity. The sample was then split into equal portions, with 20 $\mu \mathrm{L}$ of a $40 \mu \mathrm{g} / \mathrm{mL}$ of ${ }^{13} \mathrm{C}_{6}$ labeled $\mathrm{Q}$ added to one aliquot (Sample Q1) and the $20 \mu \mathrm{L}$ of a $40 \mu \mathrm{g} / \mathrm{mL}$ of ${ }^{13} \mathrm{C}_{6}$ labeled $\mathrm{HQ}$ added to the other aliquot (Sample HQ1). Prior to ${ }^{13} \mathrm{C}$ NMR analysis, $5 \mathrm{~mL}$ of the treated solutions was concentrated to $0.850 \mathrm{~mL}$ under a nitrogen stream and then transferred to a $5 \mathrm{~mm}$ NMR tube. NMR spectra acquisitions were initiated immediately upon completion of the concentration process. In a selected number of cases, the NMR spectra were examined at intermediate times before data collection was complete.

For the PP study, $92 \mathrm{~mm}$ Cambridge ${ }^{\mathrm{TM}}$ pads were treated with $800 \mu \mathrm{g}$ of either ${ }^{13} \mathrm{C}_{6}$ labeled Q or HQ by slowly, and uniformly distributing $1 \mathrm{~mL}$ of the acetone standard solution onto the pads. This amount is approximately equivalent to the total hydroquinone found in 20 cigarettes. The fortified Cambridge ${ }^{\mathrm{TM}}$ pads were then conditioned prior to smoking, for a minimum of 48 hours, in a laboratory with an environment of $75 \pm 2{ }^{\circ} \mathrm{F}$ and relative humidity at $60 \pm 2 \%$. Prior to smoking, the puff volume was verified and the machine checked for leaks. Twenty cigarettes were used in the collection, with the pad weight taken prior to and after smoking. The validity of the smoke run was determined by comparison of the WTPM and puffs/cigarette from the run with those from FTC analysis. Immediately after smoking, the pads were extracted with $25 \mathrm{~mL}$ of acetone $d_{6}$ and the 
solutions were filtered. Next, prior to ${ }^{13} \mathrm{C}$ NMR analysis, 10 $\mathrm{mL}$ of the extract from each pad was concentrated to 0.850 $\mathrm{mL}$ under a nitrogen stream and then transferred to a $5 \mathrm{~mm}$ NMR tube (Samples Q2 and HQ2). NMR spectra acquisitions were initiated immediately upon completion of the concentration process. In a selected number of cases, the NMR spectra were examined at intermediate times before data collection was complete.

\section{Smoke sample preparation for $G C-A E D$ and $G C-M S D$ analyses (see Scheme 1)}

The samples employed for ${ }^{13} \mathrm{C}$ NMR analyses were also used in the initial GC-AED and GC-MSD analyses (Samples Q1, Q2, HQ1 and HQ2). Subsequently, after completing the initial analyses of the NMR samples, additional 2R4F VP smoke samples were generated as follows: 1) The VP smoke from fifteen $2 R 4 F$ cigarettes, smoked under FTC (40) conditions, was trapped in $25 \mathrm{~mL}$ of acetone at $-70{ }^{\circ} \mathrm{C}$. To $1.66 \mathrm{~mL}(1 \mathrm{cig} / 1.66 \mathrm{~mL})$ of this acetone solution was added $40 \mu \mathrm{L}$ of a standard solution, containing known amounts of either ${ }^{12} \mathrm{C}_{6} \mathrm{Q}$ or ${ }^{13} \mathrm{C}_{6} \mathrm{Q}$ at 6570 and $6800 \mathrm{ng} / \mu \mathrm{L}$, respectively (Samples Q3 and Q4). These solutions were monitored by GC-AED and GC-MSD as a function of time, and 2) the VP smoke from fifteen 2R4F cigarettes, smoked under FTC conditions, was trapped in $25 \mathrm{~mL}$ of acetone. Two samples were prepared. To the first $25 \mathrm{~mL}$ VP sample was added $40 \mu \mathrm{L}$ of ${ }^{12} \mathrm{C}$ quinone at 6570 $\mathrm{ng} / \mu \mathrm{L}$ in acetone (Sample Q5). To the second $25 \mathrm{~mL} \mathrm{VP}$ sample was added $40 \mu \mathrm{L}$ of ${ }^{13} \mathrm{C}_{6}$ quinone at $6800 \mathrm{ng} / \mu \mathrm{L}$ in acetone (Sample Q6). These two treated solutions were allowed to stand at room temperature for 96 hours. After this time, the solutions were concentrated under dry nitrogen at $40{ }^{\circ} \mathrm{C}$ to approximately $500 \mu \mathrm{L}$ using a Zymark RotoVap. The solutions were transferred to GC vials and injected into the GC-AED and GC-MSD systems.

\section{RESULTS AND DISCUSSION}

\section{${ }^{13} \mathrm{C}$ nuclear magnetic resonance data}

${ }^{13} \mathrm{C}$ NMR spectra as generally acquired do not possess the quantitative characteristics of their proton counter parts. Thus, in general, the main details of information available from the ${ }^{13} \mathrm{C}$ NMR spectra are chemical shifts. Due to the relatively wide range of chemical shifts present in organic carbons, $\sim 250 \mathrm{ppm}$, relatively specific structural assignments can be made as a function of the chemical shifts appearing in any ${ }^{13} \mathrm{C}$ NMR spectrum. The ${ }^{13} \mathrm{C}$ NMR spectra of uniformly ${ }^{13} \mathrm{C}_{6}$ labeled $\mathrm{HQ}$ and $\mathrm{Q}$ appeared as multiplets. These multiplets were due to ${ }^{13} \mathrm{C}-{ }^{13} \mathrm{C}$ coupling and not ${ }^{13} \mathrm{C}-{ }^{1} \mathrm{H}$ coupling. For ${ }^{13} \mathrm{C}_{6}$ labeled $\mathrm{HQ}$ the multiplets were centered at $150 \mathrm{ppm}$ and $115.3 \mathrm{ppm}$, corresponding to the hydroxyl-substituted aromatic carbons and the proton-substituted aromatic carbons, respectively. For ${ }^{13} \mathrm{C}_{6}$ labeled Q the multiplets were centered at $186.19 \mathrm{ppm}$ and $135.96 \mathrm{ppm}$, corresponding to the carbonyl-substituted carbons and the alkene-proton-substituted carbons, respectively. These chemical shift values were consistent with the literature (41). The relative intensities of the responses arising from carbons with protons versus carbons with functional groups attached were consistent with known differences in carbon spin-lattice relaxation times. Such differences can be used as an interpretative tool in assigning structures to unknown molecules. It is important to note that the chemical shifts for the carbons of HQ and $\mathrm{Q}$ are very distinct one from another, affording the capability to readily distinguish between the two structures. Relatively fresh, $<24$ hours old, ${ }^{13} \mathrm{C}$ NMR spectra of particulate phase (PP) smoke treated with ${ }^{13} \mathrm{C}_{6}$ labeled $\mathrm{Q}$ (Sample Q2) and ${ }^{13} \mathrm{C}_{6}$ labeled HQ (Sample HQ2) possessed not only resonances associated with the labeled compounds but resonances linked with nicotine and glycerine. The ${ }^{13} \mathrm{C}$ NMR data revealed that the treatment of 2R4F PP smoke with ${ }^{13} \mathrm{C}_{6}$ labeled $\mathrm{Q}$ resulted in conversion of the $\mathrm{Q}$ to ${ }^{13} \mathrm{C}_{6} \mathrm{HQ}$. Resonances associated with molecules enriched with ${ }^{13} \mathrm{C}$ other than HQ were not detected. More specifically, the resonances linked to ${ }^{13} \mathrm{C}_{6} \mathrm{Q}, 136.0$ and $186.2 \mathrm{ppm}$ were found to have completely disappeared and in their place resonances at 115.5 and $150.0 \mathrm{ppm}$ were observed, directly consistent with ${ }^{13} \mathrm{C}_{6} \mathrm{HQ}$. Contrastingly, no detectable changes in the ${ }^{13} \mathrm{C}$ NMR spectra were observed with PP smoke samples treated with ${ }^{13} \mathrm{C}_{6} \mathrm{HQ}$. These results indicate that the $\mathrm{PP}$ smoke of $2 \mathrm{R} 4 \mathrm{~F}$ smoke was reducing relative to the $\mathrm{Q} / \mathrm{HQ}$ reaction(s). This observation was consistent with the literature $(3,42)$.

Relatively fresh, $<24$ hours old, ${ }^{13} \mathrm{C}$ NMR spectra of VP smoke treated with ${ }^{13} \mathrm{C}_{6}$ labeled Q (Sample Q1) and ${ }^{13} \mathrm{C}_{6}$ labeled HQ (Sample HQ1) possessed resonances associated with the labeled compounds but were relatively simple and revealed no additional resonances such as those arising from glycerin and nicotine readily evident in the spectrum of 2R4F PP smoke, see discussion in the paragraph above. Examination of the ${ }^{13} \mathrm{C}$ NMR spectra of the VP samples treated with uniformly labeled ${ }^{13} \mathrm{C}_{6} \mathrm{Q}$ and ${ }^{13} \mathrm{C}_{6} \mathrm{HQ}$ revealed similar effects to those found for PP. More specifically, treatment of the VP smoke with uniformly labeled quinone resulted in conversion of $\mathrm{Q}$ to HQ (Sample Q1). Secondly, treatment with ${ }^{13} \mathrm{C}_{6} \mathrm{HQ}$ produced ${ }^{13} \mathrm{C}$ spectra consistent with ${ }^{13} \mathrm{C}_{6} \mathrm{HQ}$, that is, reactions resulting in the depletion of ${ }^{13} \mathrm{C}_{6} \mathrm{HQ}$ were not observed (Sample HQ1). One exception to the general aspects of the ${ }^{13} \mathrm{C}$ data was discovered during the collection of ${ }^{13} \mathrm{C}$ NMR data on sample Q1 after approximately 12 hours of data collection, that is, the ${ }^{13} \mathrm{C}$ NMR spectrum of sample Q1 wherein the 2R4F VP sample had been treated with ${ }^{13} \mathrm{C}_{6} \mathrm{Q}$. Equally intense resonances, in addition to those assignable to ${ }^{13} \mathrm{C}_{6} \mathrm{HQ}$, were readily and easily observed in this intermediate ${ }^{13} \mathrm{C}$ NMR spectrum. These new resonances arising from labeled ${ }^{13} \mathrm{C}$ were located at 53-48, 128-129, 142, and $199 \mathrm{ppm}$. Resonances in these regions can be generally assigned to certain types of carbons: 1) 53-48, aliphatic carbons with functional groups attached, 2) 128-129, unsaturated carbons, i.e., alkene-like carbons, 3) 142, alkene-like carbons, 4) 199, carbonyl carbons. Special note should be taken at this point because these resonances will be shown to play a notable role in discernment of the structure of this product. While decoupled ${ }^{13} \mathrm{C}$ NMR spectral acquisitions are not routinely employed for quantitative purposes, an approximate $50 \%$ reduction in ${ }^{13} \mathrm{C}_{6} \mathrm{Q}$ signal intensity was observed after 24 hours.

Thus, armed with the chemical shift information from possible reactions of the ${ }^{13} \mathrm{C}_{6} \mathrm{Q}$, a series of structures was 


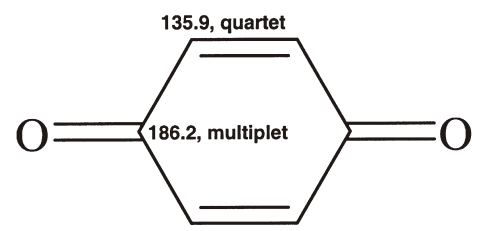

Figure 1. Quinone ${ }^{13} \mathrm{C}_{6}$ NMR chemical shifts, measured; $2 \mathrm{R} 4 \mathrm{~F}$ VP + Q; produced multiplets at $142,199,53-48,128-129$

hypothesized in an attempt to assign a structure (s) to the degradation product(s). Figures 1 and 2 contain the structures and chemical shifts for Q and HQ respectively. To facilitate this effort, predictive web-based software from Colby College (43) was employed to predict the ${ }^{13} \mathrm{C}$ chemical shifts for the proposed structures, Figures 3 and 4. Figures 1-4 are structured such that the measured/predicted chemical shifts are listed next to the appropriate carbon and the observed new resonances are listed below. The following discussion is a step by step assessment of observed versus predicted/measured chemical shifts aimed at building a structure consistent with observed chemical shifts produced by $2 \mathrm{R} 4 \mathrm{~F}$ VP with added ${ }^{13} \mathrm{C}_{6} \mathrm{Q}$ (2R4F VP+ ${ }^{13} \mathrm{C}_{6} \mathrm{Q}$, Sample Q1):

- The chemical shift for quinone and hydroquinone, Figures 1 and 2, bear no resemblance to the chemical shifts observed for $2 \mathrm{R} 4 \mathrm{~F}$ VP $+{ }^{13} \mathrm{C}_{6} \mathrm{Q}$, thus, a different product is being produced.

- Hydrolysis of carbon-carbon double bonds is a common reaction. Such a reaction with quinone could produce structures pictured in Figures 3 and 4 . The predicted resonances for these hydroxyl containing structures, 3a, 3c, 3f, 3g, 4c, and 4d, bear no resemblance to the chemical shifts observed for $2 \mathrm{R} 4 \mathrm{~F}$ VP + ${ }^{13} \mathrm{C}_{6} \mathrm{Q}$, thus, a hydroxyl compound is not likely.

- Complete reduction of both carbon-carbon double bonds, while somewhat unlikely, would yield the

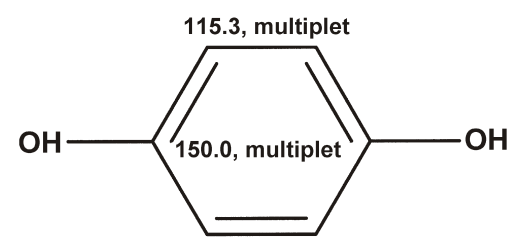

Figure 2. Hydroquinone ${ }^{13} \mathrm{C}_{6}$ NMR chemical shifts, measured; 2R4F VP + Q; produced multiplets at 142, 199, 53-48, 128-129

structure appearing in Figure 3b. The predicted resonances for this compound bear no resemblance to the chemical shifts observed for $2 \mathrm{R} 4 \mathrm{~F}$ VP $+{ }^{13} \mathrm{C}_{6} \mathrm{Q}$, thus, the presence of a fully reduced compound is not likely.

- A ring opening reaction, via reaction with free radicals is a possibility that would yield structures depicted by Figure $3 \mathrm{~d}, 3 \mathrm{e}, 3 \mathrm{f}$, and $3 \mathrm{~g}$. Such ring openings necessitate the generation/production of a saturated methyl group. Saturated methyl groups have distinct ${ }^{13} \mathrm{C}$ chemical shift values normally found in a relatively narrow range of 30 to $10 \mathrm{ppm}$. The predicted resonances for these ring opened compounds bear no resemblance to the chemical shifts observed for $2 \mathrm{R} 4 \mathrm{~F}$ $\mathrm{VP}+{ }^{13} \mathrm{C}_{6} \mathrm{Q}$, thus, a ring opened compound having saturated methyl groups is not likely.

- A ring opening reaction via hydrolysis would yield geometrical isomers represented by two compounds in Figure 3. The predicted resonances for these ring opened compounds, Figure $3 \mathrm{f}$ and $3 \mathrm{~g}$, with terminal hydroxyl groups bear no resemblance to the chemical shifts observed for $2 \mathrm{R} 4 \mathrm{~F} V \mathrm{VP}+{ }^{13} \mathrm{C}_{6} \mathrm{Q}$, thus, a ring opened compound having terminal hydroxyl groups is not likely.

- Substitution of a proton with a methyl group, via a free radical reaction could yield compounds represented in Figure $4 \mathrm{a}$ and $4 \mathrm{~b}$. Again saturated methyl groups have a distinct ${ }^{13} \mathrm{C}$ chemical shift normally found in a
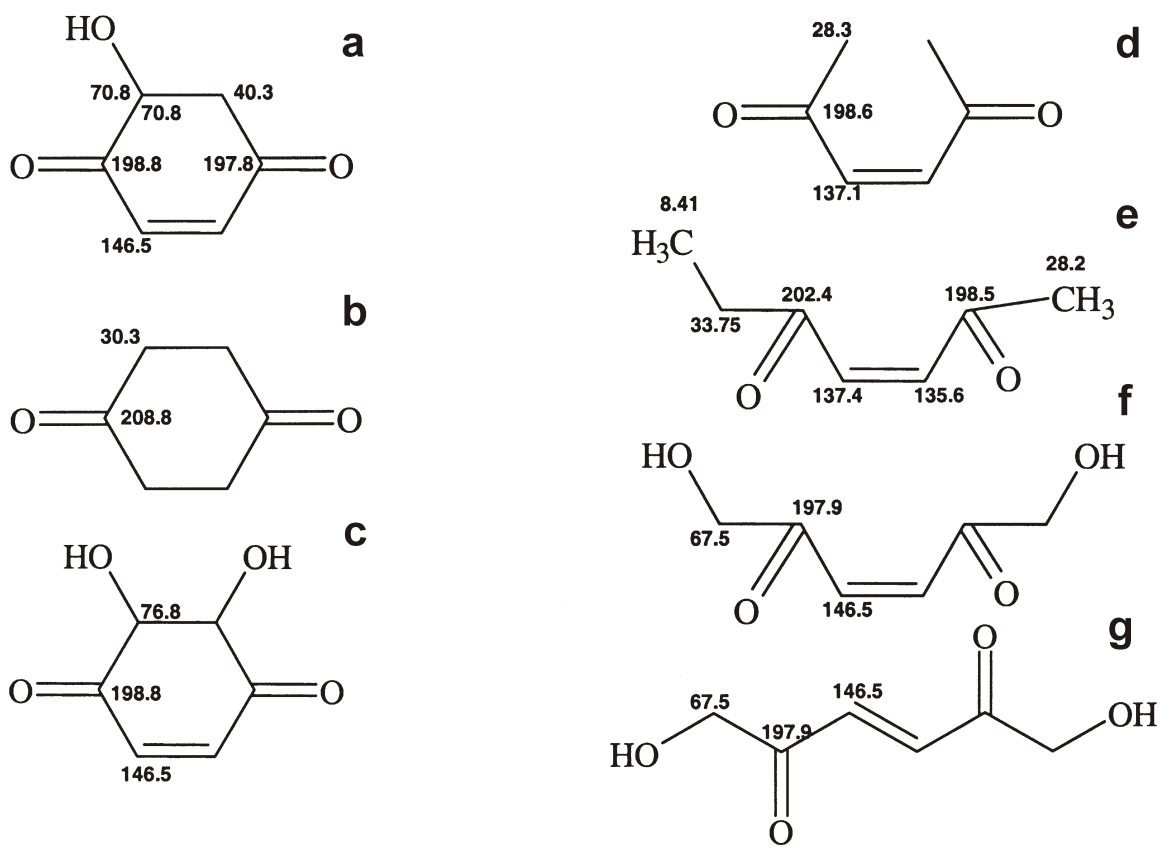

Figure 3. ${ }^{13} \mathrm{C}$ NMR chemical shifts, predicted; 2R4F VP + Q; produced multiplets at 142, 199, 53-48, 128-129 

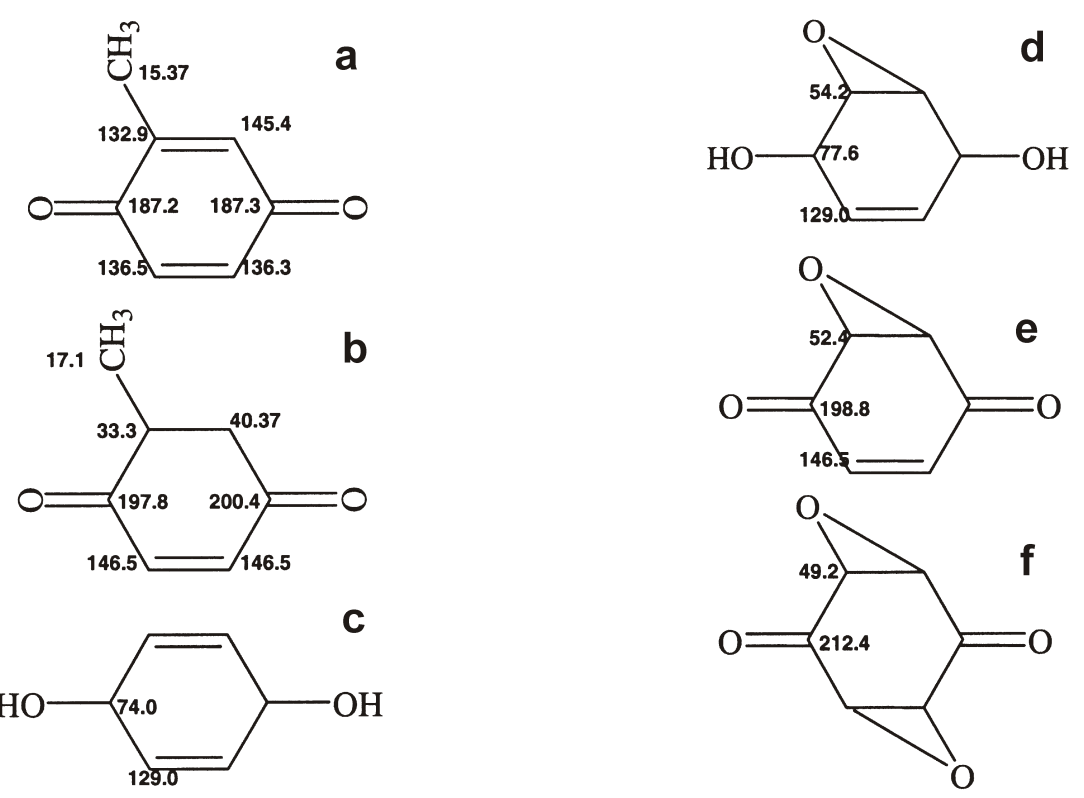

Figure 4. ${ }^{13} \mathrm{C}$ NMR chemical shifts, predicted; $2 \mathrm{R} 4 \mathrm{~F}$ VP + Q; produced multiplets at $142,199,53-48,128-129$

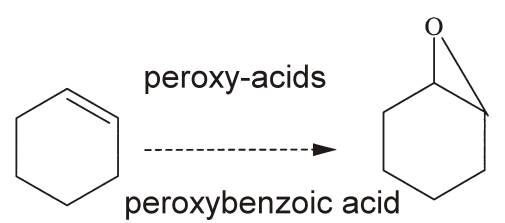

Figure 5. Preparation of epoxides

relatively narrow range of 30 to $10 \mathrm{ppm}$. The absence of any methyl resonances in $2 \mathrm{R} 4 \mathrm{~F} \mathrm{VP}+{ }^{13} \mathrm{C}_{6} \mathrm{Q}$ strongly suggests that these reactions are not occurring or at least relatively minor in scope.

- Complete reduction of the carbonyl groups to hydroxyl groups, while maintaining the carbon-carbon double bond character of the quinone would yield the structures appearing in Figure $4 \mathrm{c}$ and $4 \mathrm{~d}$. While the predicted chemical shift of $129 \mathrm{ppm}$ aligned well with the observed 2R4F VP $+{ }^{13} \mathrm{C}_{6} \mathrm{Q}$ resonance at $128 \mathrm{ppm}$, the predicted resonance at $74 \mathrm{ppm}$ did not appear. Thus, while the product(s) may have some structural characteristics similar to those in Figure 4, the observed resonances are not completely in agreement. The resonance at 128 was very weak compared with the other resonances and further work would be required to fully assess the impact of this resonance on structural assignments.

To this point, a number of possible reaction products have been proposed and subsequently eliminated by comparing measured, predicted, and observed chemical shifts. However, the exercise has helped clarify possible structures for the reaction product of $2 \mathrm{R} 4 \mathrm{~F}$ VP $+{ }^{13} \mathrm{C}_{6} \mathrm{Q}$ (Sample Q1). More specifically: 1) the presence of a resonance at 142 ppm was deduced to be consistent with a carbon-carbon double bond contained within a closed ring system having functional groups attached to the ring, 2) the resonance at $199 \mathrm{ppm}$ was seen to be consistent with a carbonyl group within a closed ring system, 3) the resonances between 53 and $48 \mathrm{ppm}$ were consistent with a methine $(\mathrm{CH})$ group possibly having a functional group attached, 4) and the resonance at $128 \mathrm{ppm}$ was consistent with a carbon-carbon double bond within a closed ring possibly having functional groups attached, as in Figure 4c.

Cyclohexene in the presence of peroxyacids (hydrogen peroxide) readily undergoes conversion to the epoxide (44). Hydrogen peroxide is a known constituent of cigarette smoke (3). The resonances predicted from the epoxide structures appearing in Figure 4 were very consistent with the observations delineated in the paragraphs above, the exception being the relatively weak resonance at $128 \mathrm{ppm}$. Reduction of the carbonyl groups to hydroxyl groups, Figure $4 \mathrm{~d}$, still leaves the predicted resonance around $77.6 \mathrm{ppm}$, that was not witnessed in the $2 \mathrm{R} 4 \mathrm{~F}$ VP $+{ }^{13} \mathrm{C}_{6} \mathrm{Q}$ reaction mixture. Converting the compound to a bis-peroxide, Figure 4f, also did not yield an acceptable match between observed and predicted resonances.

Thus, the best candidate structural fit to the observed ${ }^{13} \mathrm{C}$ chemical shift data appeared to be the mono-epoxide appearing in Figure 4e. This prediction was in concert with one of the proposed reactions of hydroquinone/quinone systems, Figures 5 and 6 . Of note in Figure 6 was the prediction of polymers from these reactions of hydroquinone (45). Such polymer formation would render interpretation of the ${ }^{13} \mathrm{C}$ NMR data rather complex.

\section{Gas chromatography-atomic emission detection and gas chromatography-mass selective detection data}

Initial experiments employing GC-AED involved investigations into the characteristics of selected fresh, $<24$ hours, samples identical to those previously studied employing ${ }^{13} \mathrm{C}$ NMR. More specifically, Figures 7 through 9 describe the GC-AED behavior of ${ }^{13} \mathrm{C}_{6} \mathrm{HQ}$ and ${ }^{13} \mathrm{C}_{6} \mathrm{Q}$ fortified into $2 \mathrm{R} 4 \mathrm{~F}$ smoke samples, previously examined by ${ }^{13} \mathrm{C}$ NMR (Samples Q1, HQ1 and HQ2). GC-MSD data was not gathered at this point. Several influential observations were gathered from the GC-AED data appearing in Figures 7-9: 


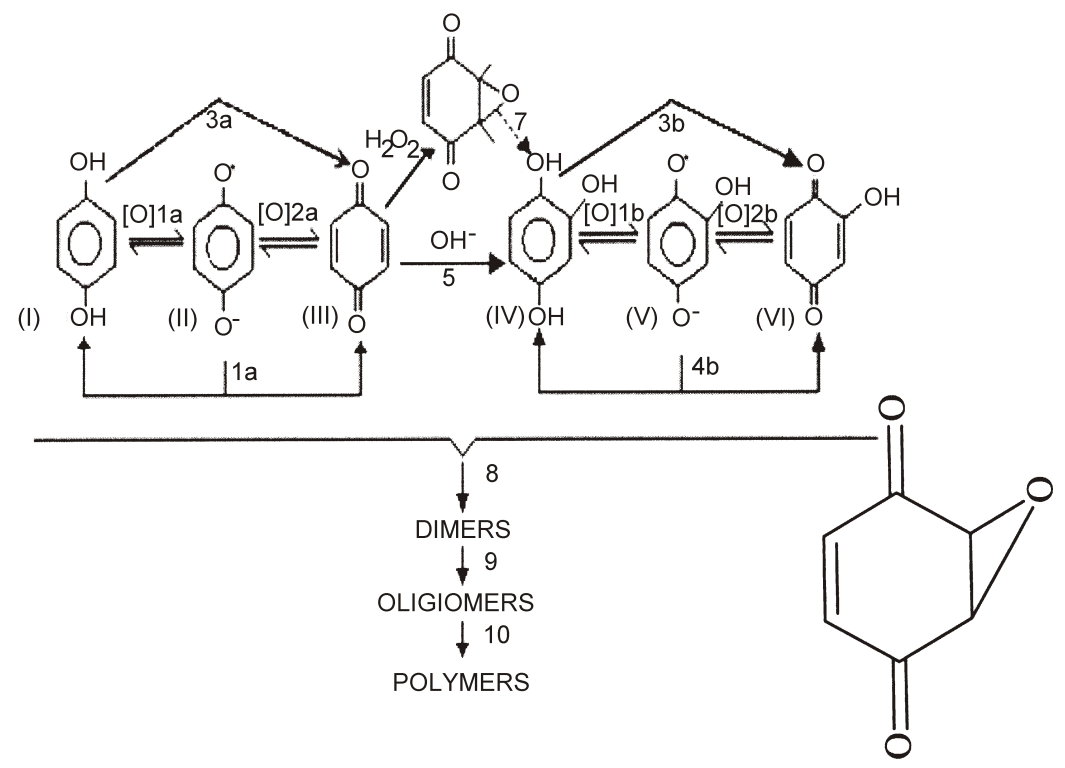

Figure 6. Oxidation of hydroquinone

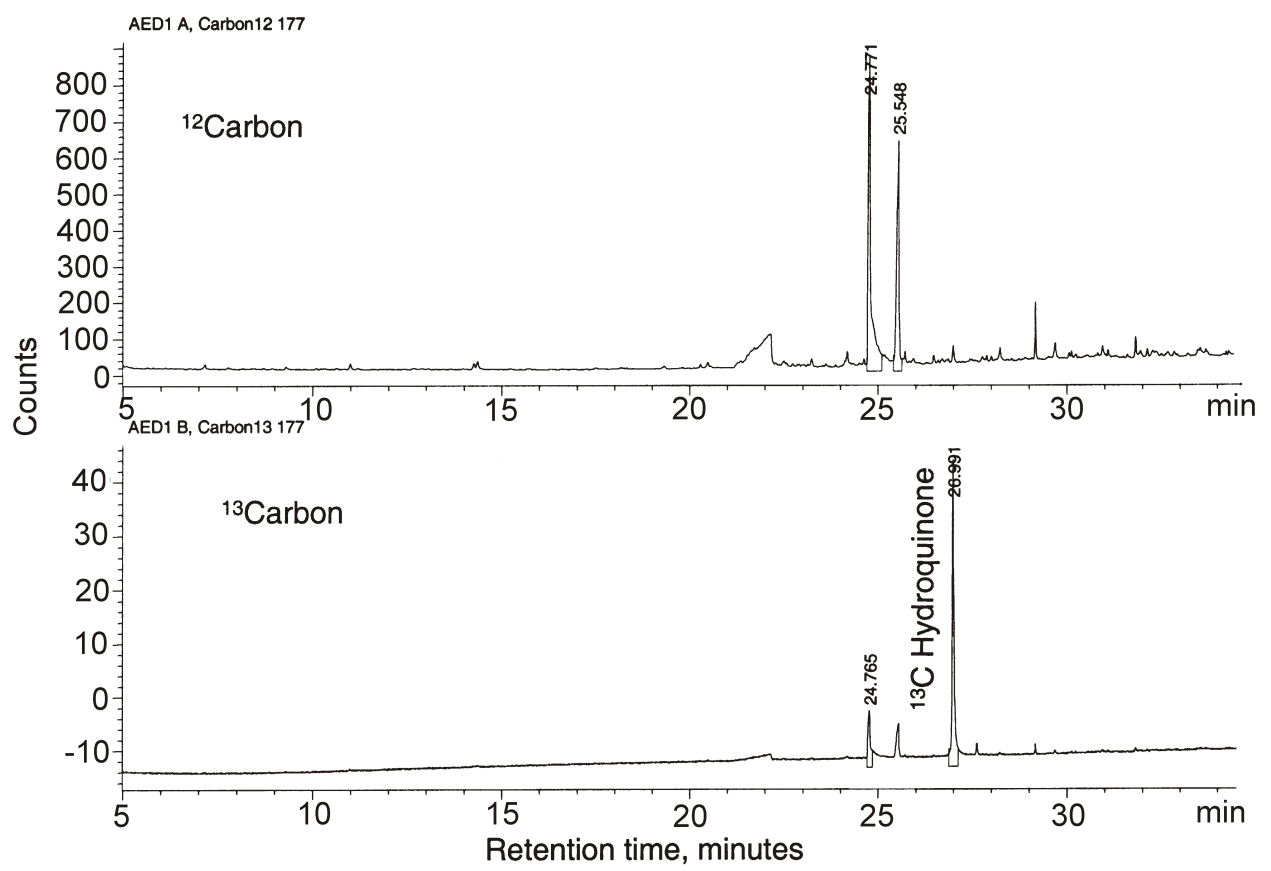

Figure 7. GC-AED traces of 2R4F PP smoke $+{ }^{13} \mathrm{C}_{6} \mathrm{HQ}$, sample HQ2

- The AED readily detected the presence of ${ }^{13} \mathrm{C}_{6} \mathrm{Q}$ and ${ }^{13} \mathrm{C}_{6} \mathrm{HQ}$ in the NMR samples

- Minimal response was noted for ${ }^{12} \mathrm{C}$ at retention times linked with the ${ }^{13} \mathrm{C}$ analogues.

- Likewise, minimal response was noted for ${ }^{13} \mathrm{C}$ at retention times linked with ${ }^{12} \mathrm{C}$ species.

- The AED results mimicked those found with NMR, wherein the MSVP smoke from the samples was found to reduce ${ }^{13} \mathrm{C}_{6} \mathrm{Q}$ to ${ }^{13} \mathrm{C}_{6} \mathrm{HQ}$, while little to no reactions were seen with ${ }^{13} \mathrm{CHQ}$.

- ${ }^{13} \mathrm{C}$ containing products not attributable to ${ }^{13} \mathrm{C}_{6} \mathrm{Q}$ or ${ }^{13} \mathrm{C}_{6} \mathrm{HQ}$ were observed.

These initial results provided information strongly suggesting that the AED would have the potential of monitoring the fate of ${ }^{13} \mathrm{C}_{6} \mathrm{Q}$ and ${ }^{13} \mathrm{C}_{6} \mathrm{HQ}$ in smoke samples. Thus, a series of experiments were conducted wherein the VP smoke from $2 \mathrm{R} 4 \mathrm{~F}$ was reacted with ${ }^{13} \mathrm{C}_{6} \mathrm{Q}$ and the reaction mixtures were monitored with time employing GC-AED and GC-MSD (Samples Q3, Q4, Q5 and Q6).

Fresh acetone solutions of 2R4F MSVP smoke were treated with ${ }^{13} \mathrm{C}_{6} \mathrm{Q}$ (Sample Q4) and ${ }^{12} \mathrm{C}_{6} \mathrm{Q}$ (Sample Q3) and the solutions were monitored as a function of time, Figure 10, revealed that ingredients of 2R4F VP smoke reacted rather rapidly with ${ }^{13} \mathrm{C}_{6} \mathrm{Q}$ to deplenish the MSD ${ }^{13} \mathrm{C}_{6} \mathrm{Q}$ response. Accompanying the stepwise decreases in ${ }^{13} \mathrm{C}_{6} \mathrm{Q}$ responses were stepwise increases in ${ }^{13} \mathrm{C}_{6} \mathrm{HQ}$ response, Figure 11. Thus, one of the primary reactions 


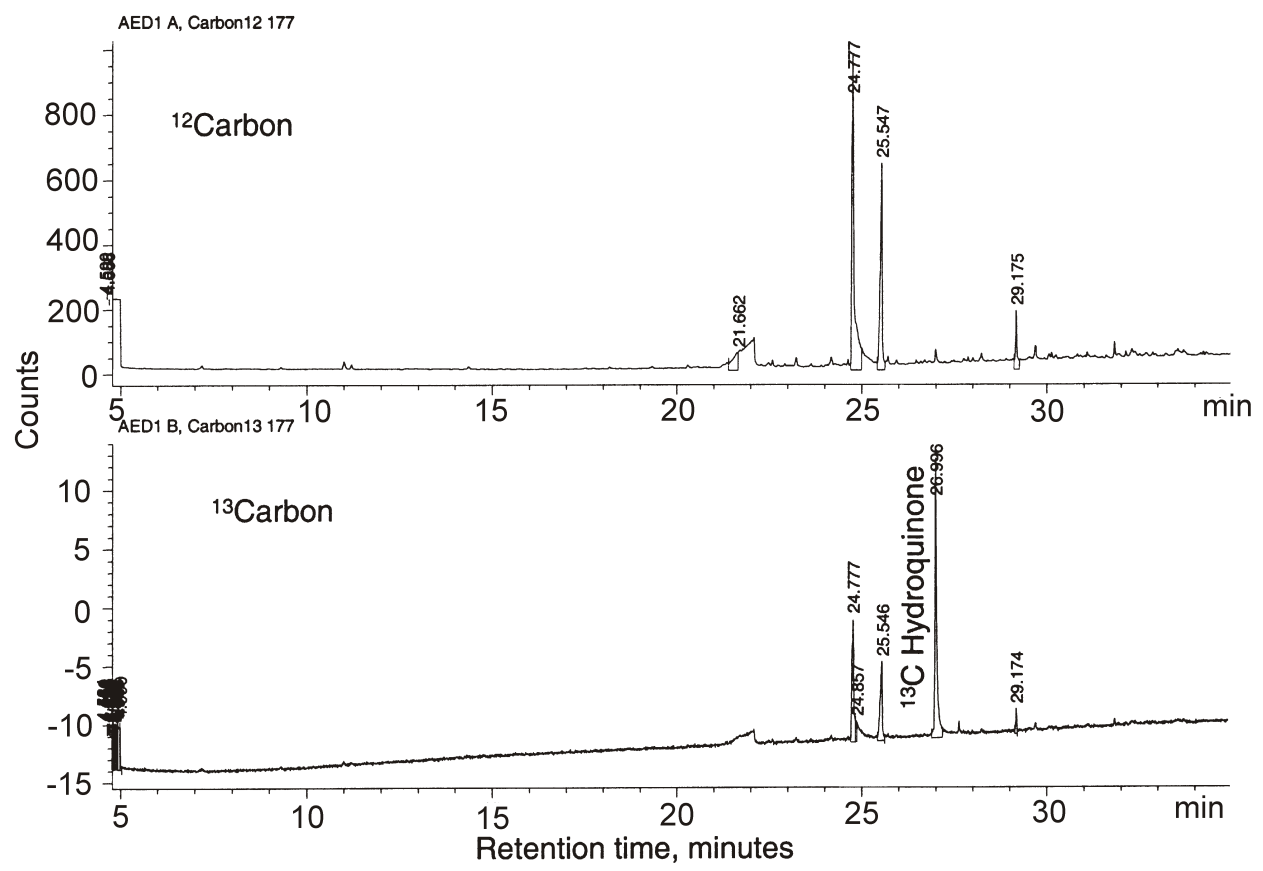

Figure 8. GC-AED traces of $2 R 4 F$ VP smoke $+{ }^{13} \mathrm{C}_{6} \mathrm{HQ}$, sample $\mathrm{HQ1}$

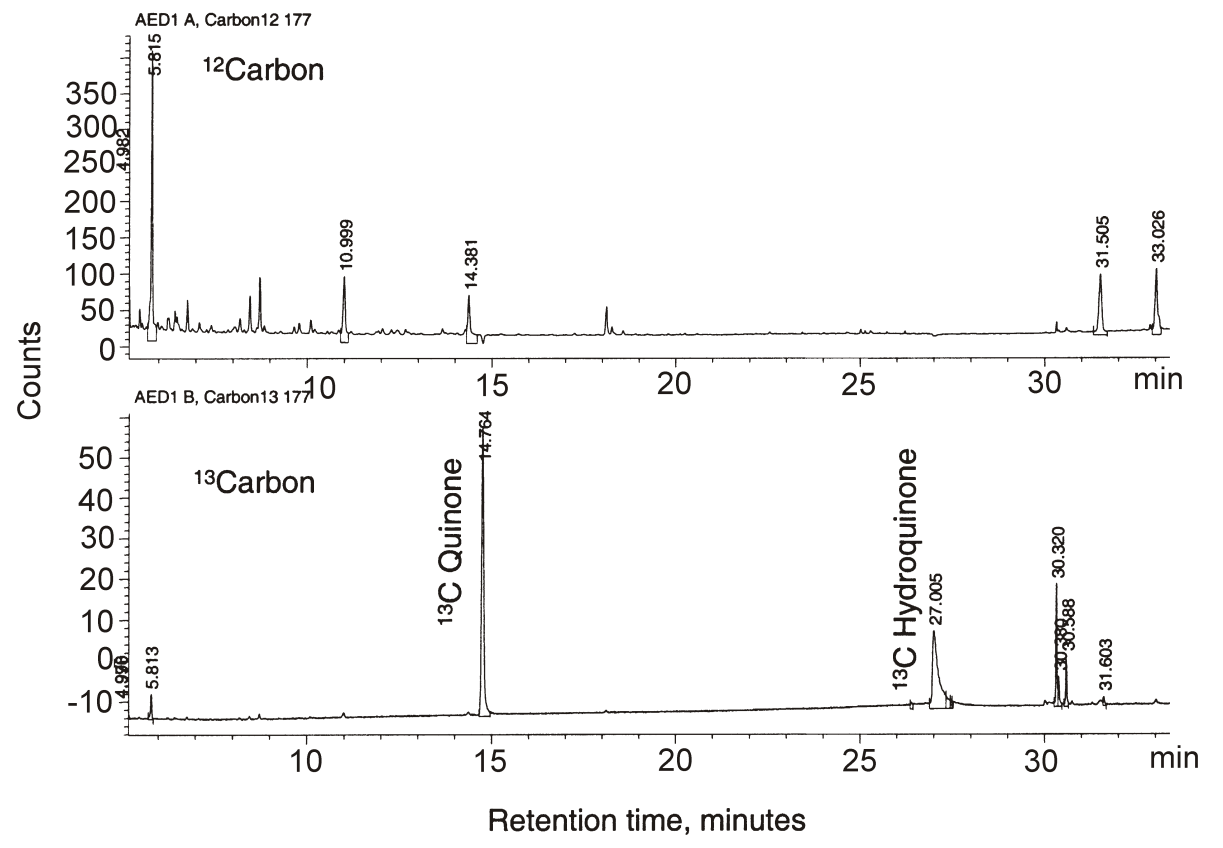

Figure 9. GC-AED traces of 2R4F VP smoke $+{ }^{13} C_{6} Q$, sample $Q 1$

observed with 2R4F VP smoke was the reduction/conversion of $\mathrm{Q}$ to HQ. The redox cycling of quinones has been related as a significant source of oxidative stress from cigarette smoke (3). Thus, it would appear from these results, that the VP component of 2R4F cigarette smoke can be expected to play a notable role in the redox cycling of quinones. It is important to mention that no ${ }^{13} \mathrm{C}$-containing species other than ${ }^{13} \mathrm{C}_{6} \mathrm{HQ}$ were observed in the GC-AED data from the reaction between $2 \mathrm{R} 4 \mathrm{~F}$ VP and ${ }^{13} \mathrm{C}_{6} \mathrm{HQ}$.
In order to take advantage of the structural information available from GC-MSD analyses, the retention times for the major components as revealed by GC-AED had to be matched by the GC-MSD system. Thus, subtle alterations in column oven programming rates and carrier gas linear velocity were made in the GC-MSD separation to result in component retention times essentially equal to those obtained via GC-AED analyses. Having accomplished this adjustment, it was now possible to directly correlate the mass spectrum of a component appearing in the GC-MSD 


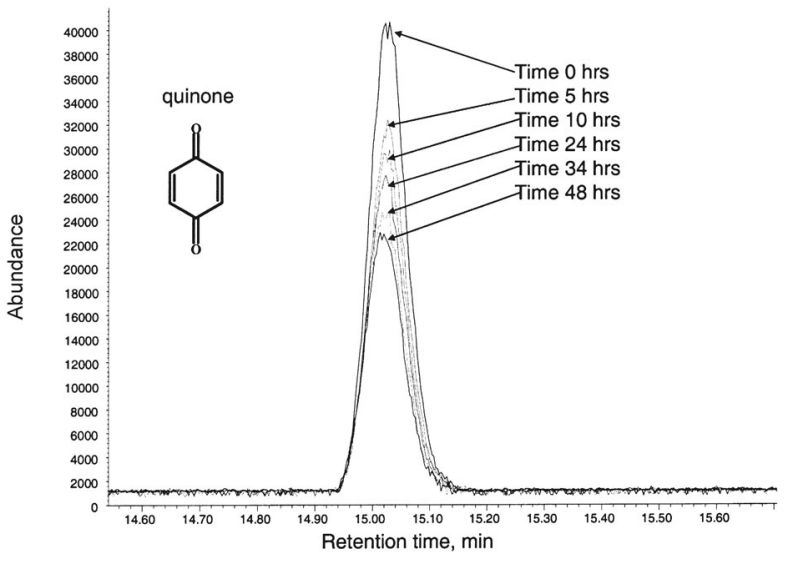

Figure 10. GC-MSD TIC's of $2 \mathrm{R} 4 \mathrm{~F}$ VP smoke $+{ }^{13} \mathrm{C}_{6} \mathrm{Q}$ as a function of time, sample Q4

analysis with the same component appearing in the GCAED analysis. Results from GC-AED analyses of the NMR samples, see section on ${ }^{13} \mathrm{C}$ NMR data, clearly indicated the presence of new ${ }^{13} \mathrm{C}$ containing species after reaction of 2R4F VP smoke and ${ }^{13} \mathrm{C}_{6} \mathrm{Q}$. These ${ }^{13} \mathrm{C}$ containing products were found at retention times near $30 \mathrm{~min}$ with the GCAED system. Thus, after subtle adjustments, GC-MSD chromatograms resulting from analysis of selected NMR samples were reflective of those obtained from GC-AED analyses, as shown in Figure 12 for Sample Q4 after 120 hrs. Several important observations could be garnered from the GC-AED and GC-MSD data appearing in Figure 12:

- ${ }^{13} \mathrm{C}_{6} \mathrm{Q}$ was reduced to ${ }^{13} \mathrm{C}_{6} \mathrm{HQ}$ in the presence of $2 \mathrm{R} 4 \mathrm{~F}$ MSVP smoke. This result was in concert with NMR data and the literature (3).

- Several ${ }^{13} \mathrm{C}$ containing species in addition to ${ }^{13} \mathrm{C}_{6} \mathrm{HQ}$ appeared in the GC-AED chromatogram, approximately 30.3 and $30.5 \mathrm{~min}$.

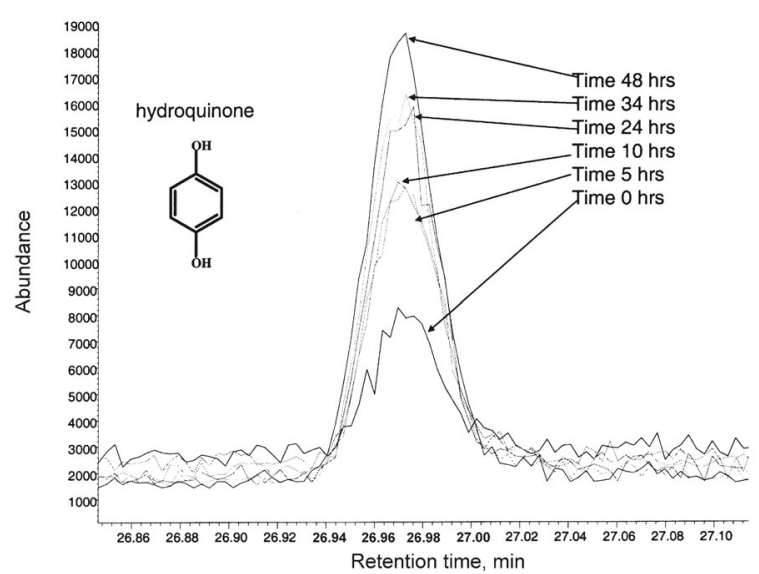

Figure 11. GC-MSD TIC's of $2 \mathrm{R} 4 \mathrm{~F}$ VP smoke $+{ }^{13} \mathrm{C}_{6} \mathrm{Q}$ as a function of time, sample Q4

- Three of these new ${ }^{13} \mathrm{C}$ containing species could readily be seen in the GC-MSD chromatogram at the same retention times.

While not entirely obvious, use of ${ }^{12} \mathrm{C}_{6} \mathrm{Q}$ was essential to understanding the reaction products of $2 \mathrm{R} 4 \mathrm{~F}$ VP smoke and ${ }^{13} \mathrm{C}_{6} \mathrm{Q}$. Since no isotope effect on reaction products, reaction rates and retention times is operative between ${ }^{12} \mathrm{C}$ and ${ }^{13} \mathrm{C}$, a direct correlation of the mass spectra between reaction products employing the two isotopes is and was possible. Furthermore, use of ${ }^{12} \mathrm{C}_{6} \mathrm{Q}$ facilitated and simplified the interpretation of the mass spectra associated with the new reaction products.

Having clearly established the presence and retention times associated with reaction products between ${ }^{13} \mathrm{C}_{6} \mathrm{Q}$ and 2R4F MSVP smoke (Sample Q4, aged approximately 120 hours), the characteristics of the mass spectra associated with these products were examined in depth, Figures 13 and 14 .
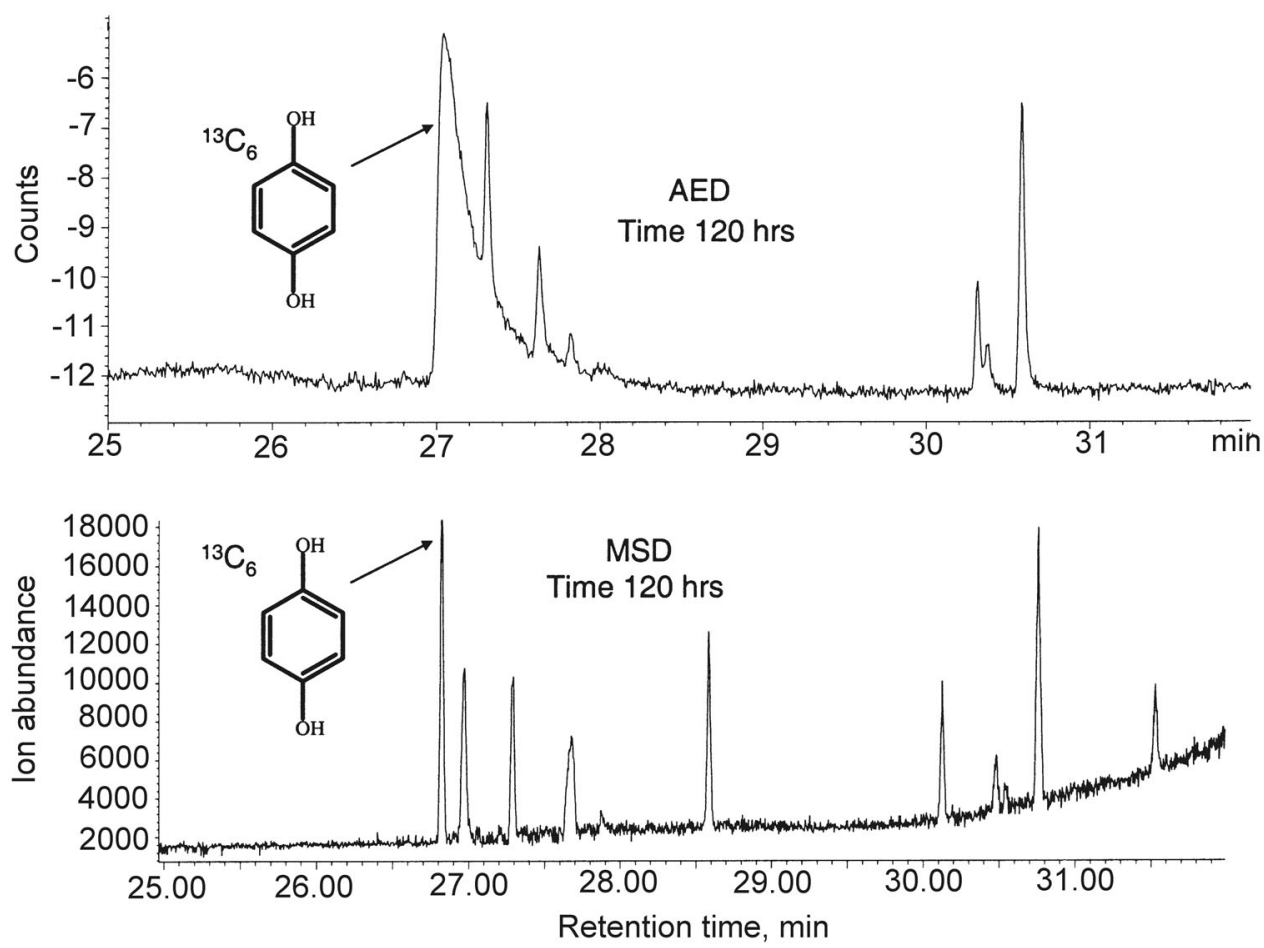

Figure 12. GC-AED counts and GC/MSD TIC of $2 \mathrm{R} 4 \mathrm{~F}$ VP smoke $+{ }^{13} \mathrm{C}_{6} \mathrm{Q}$ after 120 hours, sample $\mathrm{Q} 4$ 


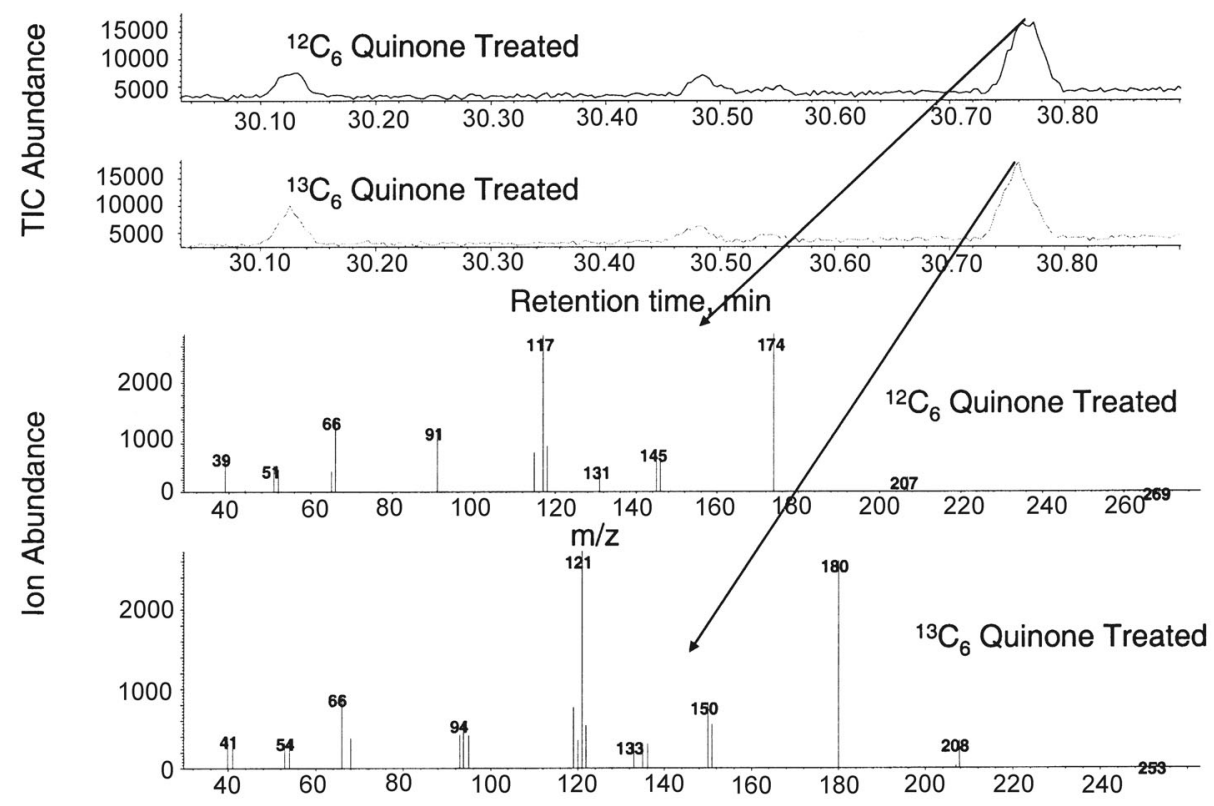

Figure 13. GC-MSD TIC's and selected mass spectra associates with ${ }^{12} C_{6} Q$ and ${ }^{13} C_{6} Q$ fortified $2 R 4 F$ VP smoke, samples $Q 3$ and $Q 4$

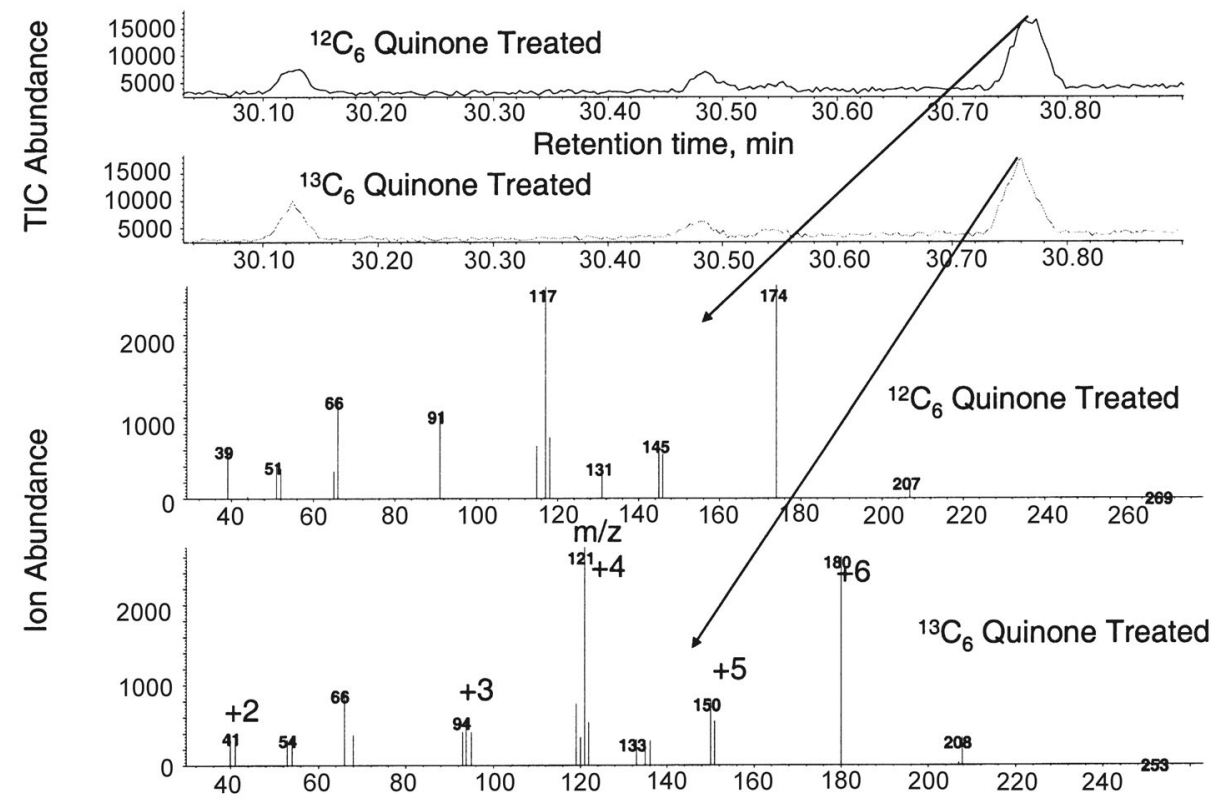

Figure 14. GC/MSD TIC's and selected mass spectra associates with ${ }^{12} C_{6} Q$ and ${ }^{13} C_{6} Q$ fortified $2 R 4 F$ VP smoke, samples $Q 3$ and $Q 4$

Several observations from the TIC and mass spectra appearing in Figure 13 (Samples Q3 and Q4) were made:

- Component retention times of ${ }^{12} \mathrm{C}_{6} \mathrm{Q}$ and ${ }^{13} \mathrm{C}_{6} \mathrm{Q}$ from GC-MSD were essentially identical and within experimental error of GC-AED retention times.

- Characteristics of mass spectra from ${ }^{12} \mathrm{C}_{6} \mathrm{Q}$ and ${ }^{13} \mathrm{C}_{6} \mathrm{Q}$ treated solutions are similar in fragmentation patterns with predictable/assignable shifts in $\mathrm{m} / \mathrm{z}$ ratios.

An interpretation of the mass spectra appearing in Figure 13 appears in Figure 14 (Sample Q4). The numbers appearing in the mass spectrum of the ${ }^{13} \mathrm{C}_{6} \mathrm{Q}$ treated Sample Q4, denote the difference in $m / z$ relative to the same ion pattern found for the ${ }^{12} \mathrm{C}_{6} \mathrm{Q}$ treated solution (Sample Q3).
Further interpretation of the two mass spectra resulted in the following:

- A $m / z$ of 174 offered a number of empirical formulas using only $\mathrm{C}, \mathrm{H}$, and $\mathrm{O}$.

- These empirical formulas were $\mathrm{C}_{8-13}, \mathrm{H}_{2-24}$ and $\mathrm{O}_{1-4}$.

- Coupling a portion of these mass spectral characteristics with previous NMR results, found that two empirical formulas seemed promising, $\mathrm{C}_{8} \mathrm{H}_{14} \mathrm{O}_{4}$ and $\mathrm{C}_{11} \mathrm{H}_{10} \mathrm{O}_{2}$.

- A gain of +6 for the ${ }^{13} \mathrm{C}_{6} \mathrm{Q}$ containing reaction strongly implicated an intact six membered ring. This was in concert with previous NMR results, vide supra.

- Systematic shifts in $m / z$ of $6,5,4,3$, and 2 strongly suggested that the structure of the component at 30.7 minutes differed only in isotopic abundance. 


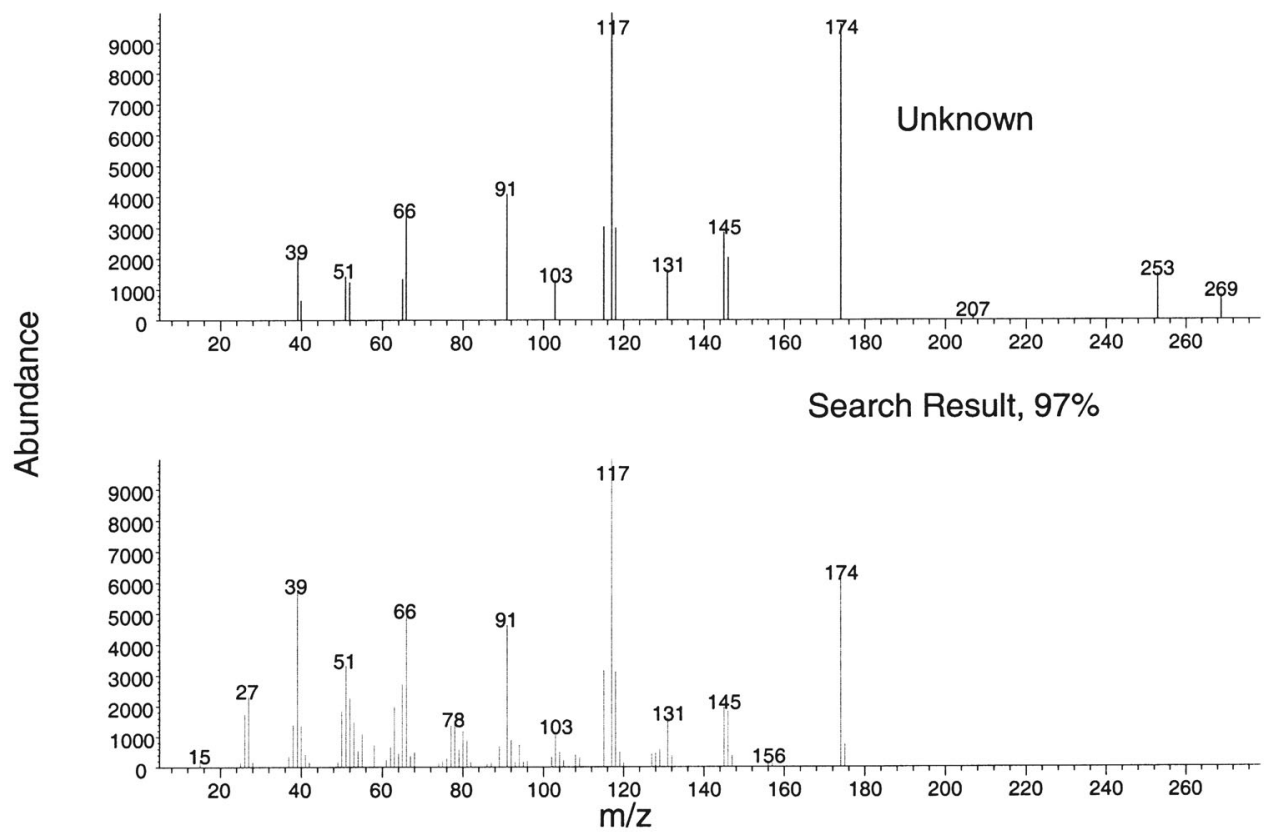

Figure 15. Library search results for component at retention time, 30.7 minutes, for ${ }^{12} C_{6} Q$ fortified $2 R 4 F$ VP smoke, sample Q3<smiles>O=C1C=CC(=O)C2C3C=CC(C3)C12</smiles>

Figure 16. Mass spectral search identification results; 1,4,4alpha,8-alpha-tetrahydro-endo-1,4-methanonaphthalene-5,8dione, for component at retention time, 30.7 minutes

- Diene candidate cyclo-1,3-pentadiene, abundant in MSVP smoke

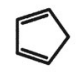

- Dienophile candidate, quinone, fortified<smiles>O=C1C=CC(=O)C=C1</smiles>

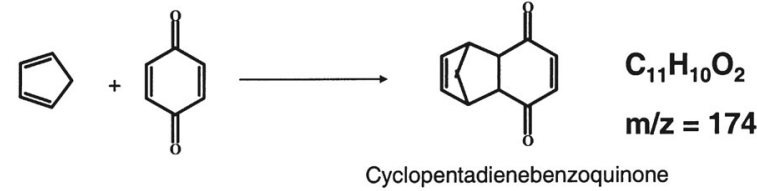

Figure 17. A Diels-Alder reaction between a diene and dienophile

Having clearly established a direct link between the reaction product from the ${ }^{12} \mathrm{C}_{6} \mathrm{Q}$ and ${ }^{13} \mathrm{C}_{6} \mathrm{Q}$ treated reactions, the mass spectrum associated with the ${ }^{12} \mathrm{C}_{6} \mathrm{Q}$ solution was closely interpreted in detail as well as subjected to a library search, Figure 15 (Sample Q3). The library search results strongly suggested, 97\% quality response, that the component appearing at retention time 30.7 minutes was tricyclo[6.2.1. $\left.0^{2,7}\right]$ undeca-4,9-diene-3,6dione or named alternatively as cyclopentadienebenzoquinone, Figure 16.

The immediate question that arises is, how could such a molecule be present as a product of $2 \mathrm{R} 4 \mathrm{~F}$ VP smoke and
Q? And what could be a logical source of such a molecule? That is, what molecule(s) could be present in $2 \mathrm{R} 4 \mathrm{~F}$ VP smoke that would react with $\mathrm{Q}$ to produce such a molecule? A closer look at the structure coupled with the proposed name, cyclopentadienebenzoquinone, afforded the possibility that the product could result from the Diels-Alder reaction between cyclopentadiene and benzoquinone, $\mathrm{Q}$. The first question that required an answer was: Does the VP smoke from $2 \mathrm{R} 4 \mathrm{~F}$ contain any cyclopentadiene, more specifically, cyclo-1,3-pentadiene? A GC-MSD TIC of 2R4F VP smoke revealed the presence of a relatively substantial amount of cyclo-1,3-pentadiene (46). A reaction mechanism that could account for cyclopentadienebenzoquinone is detailed in Figure 17. A Diels-Alder reaction between 1,3cyclopentadiene (diene) and benzoquinone $(\mathrm{Q}$, dienophile) would produce the compound, cyclopentadienebenzoquinone, having an empirical formula of $\mathrm{C}_{11} \mathrm{H}_{10} \mathrm{O}_{2}$ and a corresponding molecular weight of 174 . Thus, evidence from mass spectral data strongly suggested that the disappearance of ${ }^{13} \mathrm{C}_{6} \mathrm{Q}$ from $2 \mathrm{R} 4 \mathrm{~F}$ VP smoke could be accounted for, at least in part, by the formation of a DielsAlder reaction product of cyclo-1,3-pentadiene and Q. A number of confirmed $\mathrm{AED}{ }^{13} \mathrm{C}$ responses were not accompanied by ${ }^{12} \mathrm{C}$ mass spectra so as to lead to any firm assignment of structure due in part to relatively poor signal to noise for the components of interest. To possibly help address this issue, solutions which had been allowed to stand for 96 hours and concentrated from $25 \mathrm{~mL}$ to $500 \mu \mathrm{L}$ were then analyzed by GC-AED (Sample Q6) and GCMSD (Sample Q5), Figure 18. This more concentrated approach did result in a higher MSD response for the components that were shown by the GC-AED to contain ${ }^{13} \mathrm{C}$. The mass spectral characteristics of the component at retention time 30.7 minutes were identical to that discovered previously with no change in structural assignment. However, new, possibly improved, mass spectral information was now available for at least two additional components with retention times of approx. 30.47 (Figure 19) and 30.55 minutes (Figure 20). 


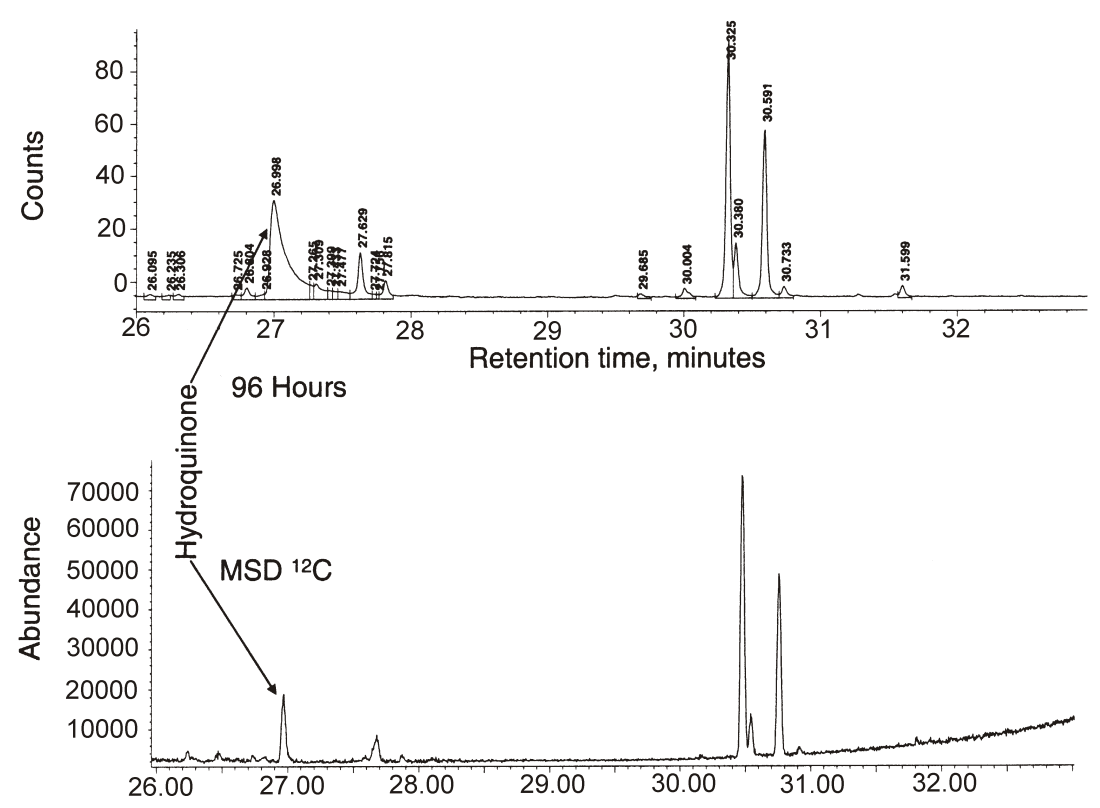

Figure 18. GC-AED counts and GC-MSD TIC of 2 R4F VP smoke fortified with ${ }^{13} C_{6} Q$ and ${ }^{12} C_{6} Q$, respectively, after 96 hours, samples Q5 and Q6
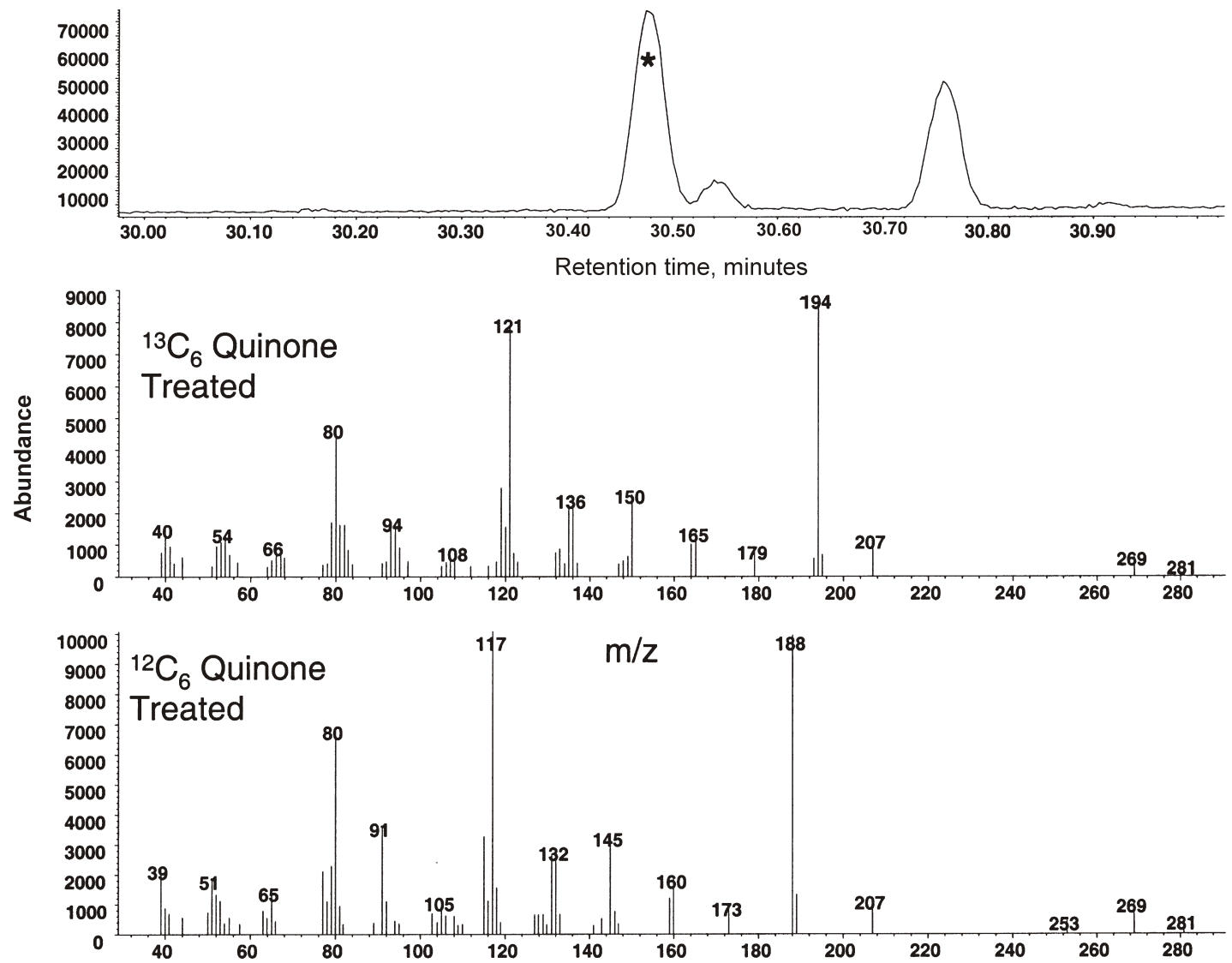

Figure 19. TIC and mass spectra associated with ${ }^{13} \mathrm{C}_{6}$ containing component (retention time $\sim 30.47 \mathrm{~min}$ ) from $2 \mathrm{R} 4 \mathrm{~F}$ VP smoke $+{ }^{13} C_{6} Q$ and ${ }^{12} C_{6} Q$, samples $Q 5$ and $Q 6$

Several important observations could be made from the data appearing in Figures 19 and 20:

- As previously seen with the ${ }^{13} \mathrm{C}$ containing component at retention time 30.7 minutes, systematic shifts in $\mathrm{m} / \mathrm{z}$ of 6 , $5,4,3$ and 2 were found for the ${ }^{13} \mathrm{C}$ containing components with retention times of 30.47 and 30.55 minutes.
- This shift strongly suggests that the structure of these components differ only in isotopic abundance relative to the comparable ${ }^{12} \mathrm{C}$ analogues.

- The shift of $m / z$ of 6 strongly suggests an intact six membered ring.

- The mass spectra of the components at retention times 

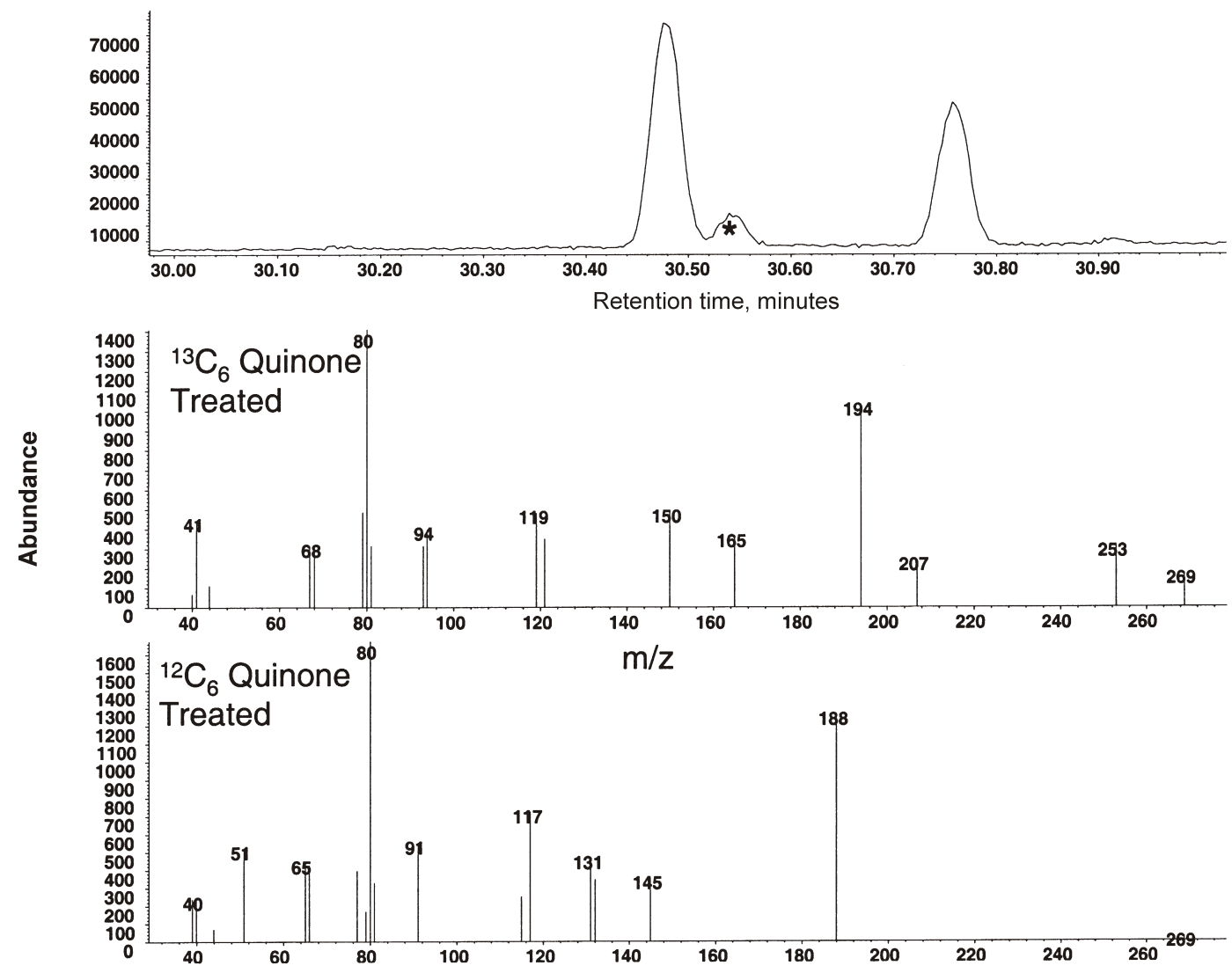

Figure 20. TIC and mass spectra associated with a ${ }^{13} \mathrm{C}_{6}$ containing component (retention time $\sim 30.55 \mathrm{~min}$ ) from $2 \mathrm{R} 4 \mathrm{~F}$ VP smoke + ${ }^{13} C_{6} Q$ and ${ }^{12} C_{6} Q$, samples $Q 5$ and $Q 6$

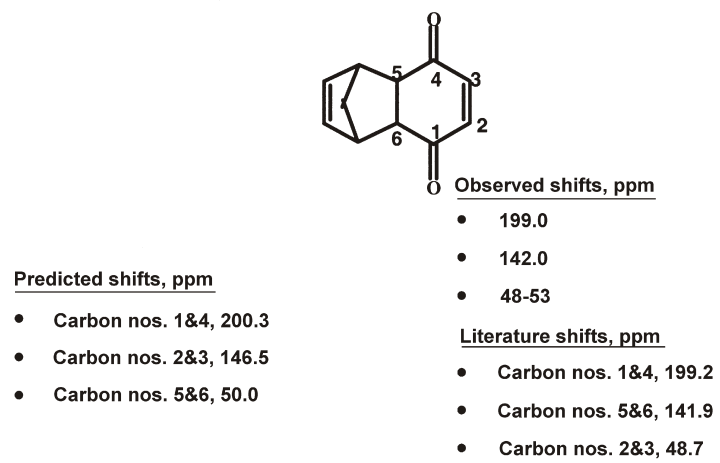

Figure 21. Proposed structure, predicted, literature, and observed ${ }^{13} \mathrm{C}$ NMR chemical shifts for cyclopentadienebenzoquinone

30.47 and 30.55 minutes are essentially identical for the ${ }^{12} \mathrm{C}$ and ${ }^{13} \mathrm{C}$ reaction mixtures, strongly suggesting the presence of isomers.

- The relative similarity in retention time would support an isomeric relationship.

- The $m / \mathrm{z}$ of the ${ }^{12} \mathrm{C}$ reaction components was 188 or 14 units greater than the $\mathrm{m} / \mathrm{z}$ of 174 observed for the component at retention time 30.7 minutes.

- The $\mathrm{m} / \mathrm{z}$ increase of 14 could readily correspond to a methylene group, $\mathrm{CH}_{2}$, or equally represent the loss of a proton followed by addition of $\mathrm{CH}_{3}$ for an overall gain of $m / z=14$.

- The fragmentation patterns associated with the components at retention times 30.47 and 30.55 minutes are very similar to the fragmentation pattern of the component located at 30.7 minutes strongly suggesting a significant structural similarity between the species.

- Based on the facts listed above, coupled with the structural assignment for the component at retention time 30.7 minutes and the presence of notable amounts of 1- and 2-methylcyclopentadiene in VP smoke (46), structural isomer assignments consisting of the DielsAlder reactions between 1- and 2-methyl-1,3-cyclopentadiene and Q would be consistent with the observations. While 1,3-cyclohexadiene would yield a similar $m / z$, no discernable amounts of 1,3-cyclohexadiene could be detected in fresh VP smoke of $2 \mathrm{R} 4 \mathrm{~F}$.

Correlation of gas chromatography-atomic emission detection and gas chromatography-mass selective detection data with ${ }^{13} \mathrm{C}$ nuclear magnetic resonance results and structural assignment

Based on ${ }^{13} \mathrm{C}$ chemical shift data of the reaction product(s) of 2R4F MSVP smoke and ${ }^{13} \mathrm{C}_{6} \mathrm{Q}$, (Sample Q1) a monoperoxide derivative of quinone was proposed, Figure $4 \mathrm{e}$. ${ }^{13} \mathrm{C}$ NMR modeling of the new proposed structure, Figure 21, from GC-AED and GC-MSD data, revealed the ${ }^{13} \mathrm{C}$ chemical shifts located in Figure 21. The literature ${ }^{13} \mathrm{C}$ chemical shifts for cyclopentadienebenzoquinone also appear in Figure 21 (47). Somewhat unexpectedly, the predicted and found ${ }^{13} \mathrm{C}$ chemical shifts for cyclopentadienebenzoquinone were very similar to those of the proposed mono-epoxide and fell close within the observed chemical shifts for the unknown species. Thus, with the 
data set taken as a whole, assignment of one of the reaction products between ${ }^{13} \mathrm{C}_{6} \mathrm{Q}$ and $2 \mathrm{R} 4 \mathrm{~F}$ MSVP smoke was very consistent with cyclopentadienebenzoquinone. Furthermore, GC-MSD and GC-AED analyses of authentic ${ }^{12} \mathrm{C}$ cyclopentadienebenzoquinone produced identical retention times and mass spectra to that of the proposed cyclopentadienebenzoquinone reaction product between 1,3-cyclopentadiene and ${ }^{12} \mathrm{C}_{6} \mathrm{Q}$ in the MSVP smoke of $2 \mathrm{R} 4 \mathrm{~F}$.

\section{CONCLUSION}

The presence of a product from a Diels-Alder reaction between a cigarette mainstream smoke component and benzoquinone is described. Results from carbon-13 nuclear magnetic resonance $\left({ }^{13} \mathrm{C} \mathrm{NMR}\right)$, gas chromatographyatomic emission detection (GC-AED), and gas chromatography-mass selective detection (GC-MSD) revealed a Diels-Alder reaction product resulting from the reaction of benzoquinone and 1,3-cyclopentadiene to yield tricyclo[6.2.1.0 $\left.0^{2,7}\right]$ undeca-4,9-diene-3,6-dione, more commonly referred to as cyclopentadienebenzoquinone. The reaction between benzoquinone and 1,3-cyclopentadiene was observed to have occurred when fresh MSVP smoke from a 2R4F cigarette, captured in acetone, was subsequently treated with ${ }^{13} \mathrm{C}_{6} \mathrm{Q}$. Other ${ }^{13} \mathrm{C}$ containing species were detected but inadequate signal to noise values prevented structural assignments. An accompanying reaction, observed to occur immediately upon addition of $\mathrm{Q}$ to the fresh 2R4F MSVP smoke in acetone, was the conversion of $\mathrm{Q}$ to HQ. These reactions provide additional information on the complexity of cigarette smoke, particularly as it relates to possible in situ reactions involving benzoquinone and hydroquinone. To date the presence of this Diels-Alder reaction product has yet to be confirmed in cigarette smoke.

\section{REFERENCES}

1. Stedman, R. L.: The chemical composition of tobacco and tobacco smoke; Chem. Rev. 68 (1967) 153-207.

2. Baker, R.R.: Smoke chemistry; in: Tobacco Production, Chemistry and Technology; edited by Davis L.D. and M.T. Nielson, Blackwell Science, Oxford, UK, 1999, pp 398-439.

3. Wooten, J.B., S. Chouchane, and T.E. McGrath: Tobacco smoke constituents affecting oxidative stress, in: Cigarette Smoke and Oxidative Stress, edited by Halliwell B.B. and H.E. Poulsen, Springer, Berlin, 2006, pp 5-46.

4. Halliwell, B.B. and H.E. Poulsen: Cigarette Smoke and Oxidative Stress, Springer, Berlin, 2006 pp 1-100.

5. Pryor, W.A., D.G. Prier and D.F. Church: Electronspin resonance study of mainstream and sidestream cigarette smoke: nature of the free radicals in gasphase smoke and in cigarette tar; Environ. Health Perspect. 47 (1983) pp 345-355.

6. Pryor ,W.A. and K. Stone: Oxidants in cigarette smoke; Anal. N.Y. Acad. Sci. 686 (1993) 12-27.

7. Maskos, Z., L. Khachatryan, R. Cueto, W.A. Pryor, and B. Dellinger: Radicals from the pyrolysis of tobacco; Energy \& Fuels 19 (2005) 791-799.
8. Chouchane, S, J.B. Wooten, F.J. Tewes, A.Wittig, B.P. Muller, D.Veltel, and J.Diekmann: Involvement of semiquinone radicals in the in vitro cytotoxicity of cigarette mainstream smoke; Chem. Res. Toxicol. 19 (2006) 1602-1610.

9. Stohs, S.J., D. Bagchi, and M.Bagchi: Toxicity of trace elements in tobacco smoke; Inhal. Toxicol. 9 (1997) 867-890.

10. Yan, F., S. Williams, G.D. Griffin, R. Jagannathan, S.E. Plunkett, K.H. Shafer, and T. Vo-Dinh: Near-realtime determination of hydrogen peroxide generated from cigarette smoke; J. Environ. Monit. 7 (2005) 681-687.

11. Pethig, R., R.C. Gascoyne, J.A. McLaughlin, and A. Szent-Gyogyi: Ascorbate-quinone interactions: electrochemical, free radical and cytotoxic properties; Proc. Natl. Acad. Sci. USA 80 (1983) 129-132.

12. Leanderson, P. and C. Tagesson: Cigarette smokeinduced DNA-damage: role of hydroquinone and catechol in the formation of the oxidative DNA-adduct, 8hydroxydeoxyguanosine; Chem. Biol. Interact. 75 (1990) 71-81.

13. Seike, K., M. Murata, S. Oikawa, Y. Hiraku, K. Hirakawa, and S. Kawanishi: Oxidative DNA damage induced by benz $[a]$ anthracene metabolites via redox cycles of quinone and unique non-quinone; Chem. Res. Toxicol. 16 (2003) 1470-1476.

14. Li,Y. and M.A. Trush: Oxidation of hydroquinone by copper: chemical mechanism and biological effects; Arch. Biochem. Biophys. 300 (1993) 346-355.

15. Ly ,Y. and M.A. Trush: DNA damage resulting from the oxidation of hydroquinone by copper: role for a $\mathrm{Cu}(\mathrm{II}) / \mathrm{Cu}(\mathrm{I})$ redox cycle and reactive oxygen generation; Carcinogenesis 14 (1993) 1303-1311.

16. Roginsky, V.A., L.M. Pisarenko, W.Bors and C. Michel: The kinetics and thermodynamics of quinonesemiquinone-hydroquinone systems under physiological conditions; J.Chem.Soc., Perkin Trans. 2 (1999) 871-876.

17. Maroz, A. and O. Brede: Reaction of radicals with benzoquinone-addition of electron transfer, Radiat. Phys. Chem. 67 (2003) 275-278.

18. Nicolaou, K.C., S.A. Snyder, T. Montangnon and G. Vassilikogiannakis: The Diels-Alder reaction in total synthesis; Angew. Chem. Int. Ed. 41 (2002) pp 1668-1698.

19. Yates, P. and K. Switlak: The $1: 1$ and 2:1 adducts of cyclopentadiene with $p$-benzoquinone; Can. J. Chem. 68 (1990) 1894-1900.

20. Rustemeier, K., R. Stabbert, H.-J. Haussmann, E. Roemer, and E.L. Carmines: Evaluation of the potential effects of ingredients added to cigarettes. Part 2: Chemical composition of mainstream smoke, Food Chem. Toxicol. 40 (2002) 93-104.

21. Counts, M. E., F.S. Hsu, and F.J. Tewes: Development of a commercial cigarette "market map" comparison methodology for evaluating new of non-conventional cigarettes; Reg. Toxicol. Pharmacol. (2006) 225-242.

22. Scholtzhauer, W.S. and O.T. Chortyk: Recent Advances in studies on the pyrosynthesis of cigarette smoke constituents, J. Anal. Appl. Pyrolysis 12 (1987) 193-222.

23. Zhuang, S., J.B. Paine, III, T.S. Sherwood, J.A. Four- 
nier, K.B. Koller, Z. Luan, and C.E. Thomas, Jr.: Filters including segmented monolithic sorbent for gas-phase filtration; U.S. Patent number 6814786, November 19, 2004.

24. Bon Aire, A.B. and E.W. Robb, II: Use of Diels-Alder adducts as tobacco additives, U.S. Patent number 3,047,433 July 31, 1962.

25. Johnson, D., B. Quimby and J. Sullivan: An atomic emission detector for gas chromatography; Amer. Lab. October (1995) 1-5.

26. Webster, C. and M. Cooke: Use of an atomic emission detector to study the variation in elemental response for chlorine, carbon, and oxygen in phenols; J. High Resol. Chromatogr. 18 (1995) 319-322.

27. Quimby, B.D. and J.J. Sullivan: Evaluation of a microwave cavity, discharge tube, and gas flow system for combined gas chromatography-atomic emission detection; Anal. Chem. 62 (1990) 1027-1034.

28. Sullivan J.J. and B.D. Quimby: Characterization of computerized photodiode array spectrometer for gas chromatograph-atomic emission spectrometry; Anal. Chem. 62 (1990) 1034-1043.

29. Juillet, Y., E. Gilbert, A. Begos, and B. Bellier: Investigation of compound-independent calibration and partial molecular formula determination by gas chromatography-atomic-emission detection for characterization of organophosphorus and organosulfur agents related to the chemical weapons convention; Anal. Bioanal. Chem. 383 (2005) 848-856.

30. Quimby, B.D., P.C. Dryden, and J.J. Sullivan: Selective detection of stable-isotope labeled compounds using gas chromatography-emission spectrometry, Synthesis and Applications of Isotopically Labeled Compounds, (1991) 1128-1132.

31. Quimby, B.D., P.A. Larson, and P.C. Dryden: A comparison of the HP G2350 AED versus HP 5921A AED for average values of MDL and selectivity for selected elements; HP Application Note 228-363, 1996.

32. Stevens, N.A., and M.F. Borgerding: Effect of column flow rate and sample injection mode on compoundindependent calibration using gas chromatography with atomic emission detection; Anal. Chem. 70 (1998) 4223-4227.

33. Yu, J., L.T. Taylor, S. Aref, J.A. Bodnar, and M.F. Borgerding: Influence of puffing parameters and filter vent blocking condition on nicotine fate in a burning cigarette part 1. Full flavor cigarettes; Beitr. Tabakforsch. Int. 22 (2006) 185-195.

34. Janak, K., C. Ostman, H. Carlsson, A. Bemgard, and A. Colmsjo: Instrument-induced effects in the analysis of polycyclic aromatic compounds by capillary gas chromatography with atomic emission detection (GCAED); J. High Resol. Chromatogr. 17 (2004) 135-140.

35. Silverstein, R.M., G.C. Bassler, and T.C. Morrill: Spectrometric Identification of Organic Compounds, John Wiley, New York, 1999, pp. 1-419.
36. Stothers, J.B.: Carbon-13 NMR Spectroscopy, Academic Press, New York, 1972, pp. 1-559.

37. Barsanti, K.C., W. Luo, L.M. Isabelle, J.F. Pankow and D.H. Peyton: Tobacco smoke particulate matter chemistry by NMR; Magn. Reson. Chem. 45 (2006) 167-170.

38. Schonher, H., H.-J. Klimisch and H.-P. Harket: Aging of cigarette smoke concentrate quantitative investigations of artifact formation by gas and particulate phase reactions; Beitr. Tabakforsch. 7 (1973) 18-23.

39. Einolf, W.N., R.N. Ferguson, J.F. Whidby, and J.F. DeBardeleben; Isolation and identification of 2,6dimethyl and 2,2,6-trimethyl-4-piperidone, artifacts produced by the reaction of cigarette smoke condensate and acetone; Beitr. Tabakforsch. 9 (1978) 208-213.

40. U.S. Federal Trade Commission: Cigarettes and related matters. Carbon monoxide, "tar", and nicotine content of cigarette smoke. Description of new machine and methods to be used in testing; Fed. Register 45 (1980) 46483-46487.

41. Stevenson, C.D., T.D. Halvorsen, and R.C. Reiter: Effect of ${ }^{13} \mathrm{C}$ substitution on the solution electron affinity of $p$-benzoquinone; J. Am. Chem. Soc. 115 (1993) 12405-12408.

42. Van der Vilet, A.: Oxidative modifications of proteins and lipids by CS; in: Cigarette Smoke and Oxidative Stress, edited by B.B. Halliwell and H.E. Poulsen, Springer-Verlag, Berlin, 2006, pp 47-74.

43. Colby College Web Site; www.colby.edu/chemistry (August 31, 2007).

44. Morrison, R.T. and R.N. Boyd: Organic Chemistry; Second Edition, Allyn and Bacon, Inc., Boston, USA, 1966.

45. Gillner, M., G.S. Moore, H.Cederburg, and K. Gustafsson: Environmental Health Criteria 157; World Health Organization, 1994, pp. 1-119.

46. Coleman, W.M.: Personal communication, 2007.

47. Yates, P. and K. Switlak: The 1:1 and 2:1 adducts of cyclopentadiene with $p$-benzoquinone; Can. J. Chem. 68 (1990) 1984-1990.

Address for correspondence:

W. M. Coleman, III

R.J. Reynolds Tobacco Company,

P.O. Box 1487 ,

Winston-Salem,

NC 27102-1487,

USA

E-mail:colemaw@rjrt.com 